\title{
9. SEDIMENTOLOGY, MINERALOGY, AND GEOCHEMISTRY OF GREEN CLAY SAMPLES FROM THE GALAPAGOS HYDROTHERMAL MOUNDS, HOLES 506, 506C, AND 507D, DEEP SEA DRILLING PROJECT LEG 70 (PRELIMINARY DATA) ${ }^{1}$
}

\author{
J. Honnorez, Rosenstiel School of Marine and Atmospheric Science, University of Miami, Miami, Florida \\ and \\ Anne-Marie Karpoff and Denise Trauth-Badaut, Institut de Géologie, Université de Strasbourg, Strasbourg, France
}

\section{INTRODUCTION}

The hydrothermal mounds on the southern flank of the Galapagos Spreading Center are characterized by the following main features:

1) They are located over a young basement $(0.5$ to $0.85 \mathrm{~m} . \mathrm{y}$. of age) in a region known for its high sedimentation rate (about $5 \mathrm{~cm} / 10^{3} \mathrm{y}$.) because it is part of the equatorial high biological productivity zone.

2) They are located in a region with generally high heat flow ( 8 to $10 \mathrm{HFU}$ ). The highest heat-flow measurements (up to $10^{3} \mathrm{HFU}$ ) correspond to mound peaks (Williams et al., 1979), where temperatures up to $15^{\circ} \mathrm{C}$ were measured during a dive of the submersible Alvin (Corliss et al., 1978).

3) They are often located on small vertical faults which displace the basement by a few meters (Lonsdale, 1977) and affect the 25- to 50-meter-thick sediment cover.

Most of these characteristics have also been observed in the other three known cases of hydrothermal deposits with mineral parageneses similar to that of the Galapagos mounds. However, the case of the hydrothermal mounds south of the Galapagos Spreading Center is unique because of the unusual thickness of the hydrothermal deposits present. The mounds are composed of several, up to 4.5-meter-thick, layers of green clays which, in one case (Hole 509B), are overlain by about 1.4 meters of Mn-oxide crust. We suspect that such a large accumulation of hydrothermal products results from the "funnelling" of the hydrothermal solutions exiting from a highly permeable basement along the faults.

This chapter reports a preliminary study of those green clays collected by hydraulic piston coring of the Galapagos mounds during Deep Sea Drilling Project (DSDP) Leg 70 of the D/V Glomar Challenger (Fig. 1).

Green clays have also been reported from three presently or recently active hydrothermal areas in or close to spreading centers.

Bischoff (1972) described a "ferroan nontronite" which is the major constituent of a 5-meter-thick bed representing the most recent facies of the Red Sea geothermal deposits. The nontronite is believed to be presently forming. The X-ray diffractogram of this nontron-

\footnotetext{
${ }^{1}$ Honnorez, J., Von Herzen, R. P., et al., Init. Repts. DSDP, 70: Washington (U.S. Govt. Printing Office).
}

ite displays a (001) peak at $13.5 \AA$ which expands after glycolation to $15.5 \AA$ and collapses to $9.5 \AA$ after heating. The (060) spacing is close to $1.53 \AA$, reflecting the partial trioctahedral character of the mineral. The nontronite is rich in ferrous iron $(3.93$ to $6.96 \% \mathrm{FeO}$, or 0.49 to $1.15 \mathrm{Fe}^{2+}$ vs. 2.55 to $3.19 \mathrm{Fe}^{3+}$ in the octahedral position) and poor in aluminum (1.8 to $2.1 \% \mathrm{Al}_{2} \mathrm{O}_{3}$ or 0.46 to $0.53 \mathrm{Al}$ in the tetrahedral position) and magnesium ( 0.81 to $1.40 \% \mathrm{MgO}$, or 0.26 to $0.41 \mathrm{Mg}$ in the octahedral position). Bischoff suggested that the nontronite precipitates in the water column as a result of mixing between cold bottom seawater and brines carrying $\mathrm{SiO}_{2}$ and $\mathrm{Fe}^{2+}$ as well as the other heavy metals. Part of the $\mathrm{Fe}^{2+}$ is oxidized during the mixing process and enters the octahedral sites of the nontronite. The nontronite settles later on the seafloor. Bischoff speculates that "the mineral is most likely unstable in the presence of seawater, and a trend toward equilibrium would probably involve K fixation and formation of glauconite."

Cann et al. (1977) studied a "friable yellow to green massive smectite" associated with manganese-oxide crusts and minor amorphous iron hydroxides coating basalt fragments dredged $3 \mathrm{~km}$ away from the axis of the Gulf of Aden spreading center. The actual relationship among the various hydrothermal components and the rock fragments is not reported. The smectite gives a broad basal peak at $14 \AA$ which expands to $17 \AA$ upon glycolation. Chemical analyses show that the smectite is iron rich (almost entirely ferric iron) and very poor in aluminum ( 0.03 to $0.11 \mathrm{Al}$ in the tetrahedral position) and magnesium ( 0.68 to $0.75 \mathrm{Mg}$ in the octahedral position). The hydrothermal origin is inferred by the trace element geochemistry of the Mn-Fe oxides. Similarly, "the trace element geochemistry of the dredged smectite... suggests strongly an origin as a direct precipitate from a hydrothermal solution..." (Cann et al., 1977).

The third known example of green clays interpreted as hydrothermal in origin was studied in great detail by Hoffert et al. (1978). Direct observations and samplings were carried out from the submersible Cyana in Transform Fault $\mathbf{A}$ of the FAMOUS area, Mid-Atlantic Ridge, at $37^{\circ} \mathrm{N}$. Hence field relationships between the various types of material collected are known, which casts light on the formation of such hydrothermal deposits. Two hydrothermal fields, each about $600 \mathrm{~m}^{2}$ in surface area, were found. The deposits form asymmetrical ridges culminating in elongated fissure-like "vents." 


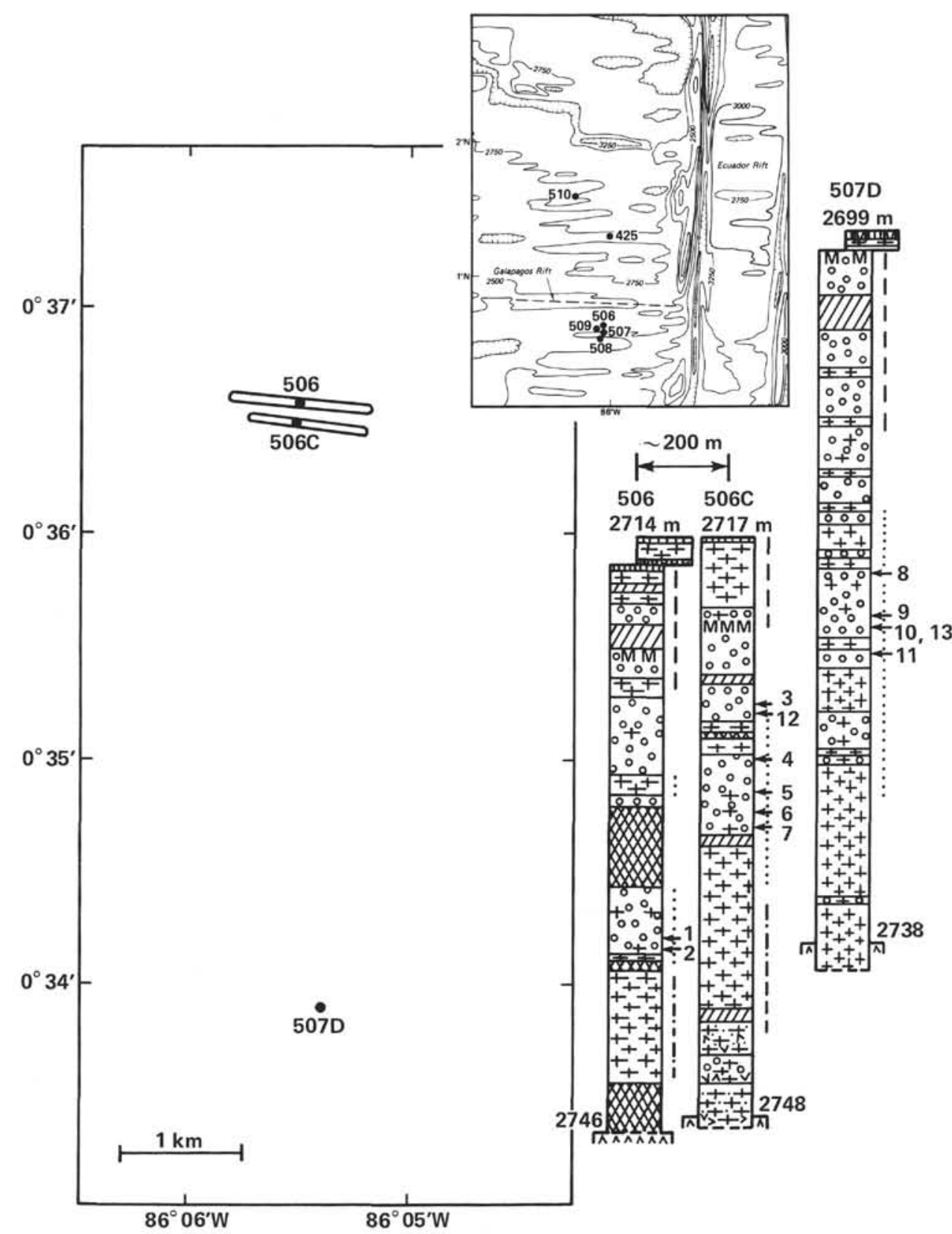

Figure 1. Geographic location and schematic lithostratigraphic sections of Holes 506, 506C, and 507D, Leg 70. $(1=$ Sample 506-6-2, 39-41 cm; $2=506-6-2,127-129 \mathrm{~cm} ; 3=506 \mathrm{C}-3-2,0-150 \mathrm{~cm} ; 4=506 \mathrm{C}$ $3-3,93-113 \mathrm{~cm} ; 5=506 \mathrm{C}-4-1,121-125 \mathrm{~cm} ; 6=506 \mathrm{C}-4-2,122-126 \mathrm{~cm} ; 7=506 \mathrm{C}-4-3,53-57 \mathrm{~cm}$; $8=507 \mathrm{D}-6-1,12-22 \mathrm{~cm} ; 9=507 \mathrm{D}-6-2,37-41 \mathrm{~cm} ; 10=507 \mathrm{D}-6-2,103-107 \mathrm{~cm} ; 11=507 \mathrm{D}-7-1,16-21$ $\mathrm{cm} ; 12=506 \mathrm{C}-3-1,0-150 \mathrm{~cm} ; 13=507 \mathrm{D}-6-2,90-130 \mathrm{~cm}$.

The "vents" appeared to be inactive because no thermal or geochemical anomalies were noticed in their vicinity.

The hydrothermal deposits lay upon semi-indurated pelagic sediments and are associated with rock fragments. They spread out in a fan-shaped pattern (with green clay-rich material more abundant near the "vents" and $\mathrm{MnO}_{2}$ crusts more abundant away from them), and their thickness decreases away from the vents. Radiochemical studies (Lalou et al., 1977) indicate that the $\mathrm{Fe}-\mathrm{Mn}$ crusts have a possible maximum age of 45,000 years.
The green clay-rich material is made up of a mixture of smectite, "hydromica"' (glauconite-celadonite), various Mn oxides, and occasionally pyrite. The "hydromicas" have a (001) basal plane at 10.1 to $10.6 \AA$ and display a rolled flake ("curls") morphology under the transmission electron microscope (TEM). The smectites have an expandable (001) basal plane at about $16 \AA$, a (020) plane at $4.5 \AA$, a (200) plane at $2.65 \AA$, and a (060) plane at $1.52 \AA$, and they exhibit a lath-like morphology. Hoffert et al. (1978) identified the dioctahedral smectites as nontronites. The chemical composition 
of the clay-rich materials indicates that they are very rich in $\mathrm{Fe}_{2} \mathrm{O}_{3}(32.3$ to $38.6 \%)$ and poor in $\mathrm{MgO}(\sim 2.75 \%)$ and $\mathrm{Al}_{2} \mathrm{O}_{3}(0.2-0.4 \%)$, which agrees with the chemistries of glauconite-celadonite and nontronite. However, the relatively low silica contents ( 30.2 to $44.4 \%$ ) and the very high $\mathrm{Fe}_{2} \mathrm{O}_{3}$ contents indicate that the clays are mixed with iron hydroxides.

Nontronite and $\mathrm{Fe}-\mathrm{Mn}$ oxide were dredged from the Explorer Rise, a spreading center in the NE Pacific (Grill et al., 1981). Several flat slabs are made up of yellow green clays and orange to black Fe-Mn oxides joined along a surface parallel to the flat face of the slabs. Both clays and oxides display a well-defined internal layering parallel to the boundary and underlined at irregular intervals by thin $(<1 \mathrm{~mm})$ laminae of an orange mixture between iron hydroxides and iron-rich clays.

The X-ray diffractions (XRD) were carried out on mixtures of clay, various $\mathrm{Fe}-\mathrm{Mn}$ oxides, and sometimes possible traces of detrital minerals. The clay appears to be dioctahedral smectite with a $(060)$ plane at $1.52 \AA$. However, the XRD does not seem to have been detailed enough to indicate the presence (except in one sample) of a celadonite-glauconite type of mica. The unit cell of the most smectitic samples, or less than $2 \mu \mathrm{m}$ isolated fraction, is said by Grill et al. (1981) to be virtually identical to that of the green clay dredged from the Galapagos mounds by Corliss et al. (1978). However, the Explorer Rise samples are generally richer in $\mathrm{Al}$ both in the tetrahedral and octahedral positions, and in $\mathrm{Mg}$ in the octahedral position, and much poorer in $\mathrm{Fe}^{3+}$ in the tetrahedral position. Again, the trace element geochemistry of the various clays and $\mathrm{Fe}-\mathrm{Mn}$ oxides is used as a basis to conclude that these materials are of hydrothermal origin (Grill et al., 1981). These authors suggested that the smectites precipitated first from reducing hydrothermal solutions which became progressively oxygenated by increased mixing with seawater, hence precipitating $\mathrm{Fe}-\mathrm{Mn}$ oxides. The age of the hydrothermal deposit is unknown, but it cannot be older than the underlying basement, which is $0.25 \mathrm{~m} . \mathrm{y}$. old.

\section{SEDIMENTOLOGY}

Thirteen samples of green clays from Holes 506, 506C , and 507D were studied in detail. Five of these samples were unusually large according to Deep Sea Drilling Project (DSDP) standards because they had been collected directly on the sampling table from material which had fallen from the core liners after these had been split in half. (Care had been taken to wash the table surface of debris from preceding cores.) The centimeter interval of the large sample numbers indicates the core interval from which the sediment fell. In two cases, the entire length of the core section is reported because the sample is an aggregate of several subsamples from different positions of the core section. The reader should refer to the corresponding site summaries for a detailed description of the sedimentology and stratigraphy of the three holes from which our samples were collected. A summary of these descriptions can be found in the summary chapter and in Honnorez et al. (1981).
The sedimentological study was carried out using smear slides of the bulk sediment. These were prepared following the standard DSDP method and under conditions as strictly reproducible as possible in order to compare the different components among the various samples.

Study of the smear slides under the microscope allowed us to distinguish three major types of clay particles on the basis of their morphological characteristics. In addition, several other types of accessory components were recognized. The sedimentological observations are summarized in Table 1 . The three major types of clay components are as follows:

1) Type 1 particles are irregularly shaped flakes displaying a bright to olive green color; they are extremely variable in size. Their outlines are well defined and rarely curled. Type 1 particles are characterized by a rim which appears darker (in plane polarized light) and is birefringent between crossed polars. Type 1 particles make up Sample 506-6-2, 39-41 cm, almost completely, exhibiting the brightest green color of all the studied samples (see Plate 1, Figs. 1, 2). They were also observed in Samples 507D-6-2, 37-41 cm and 507D-6-2, $90-130 \mathrm{~cm}$.

2) Type 2 particles exhibit variable shades of green. Their most common color is pale green, but in samples from Hole 506C, they display a darker olive green to brown color. Type 2 particles form granular aggregates with irregular outlines, uniform birefringence, and extremely variable size. They are the most frequent and abundant type in all samples studied except Sample 506-6-2, 39-41 cm. They are best represented in Samples 506-6-2, 127-129 cm and 506C-3-3, 93-113 (see Plate 1, Figs. 3, 4).

3) Type 3 particles generally exhibit an olive green color. They have an outline similar to Type 1 particles but are isotropic and do not display darker rims. Their outline is well defined, and sometimes the particles appear to be made up of thin superimposed platelets. Type 3 particles are most frequent in the samples from Hole 506C, where they are generally associated with Type 2 particles (see Plate 1, Figs. 5, 6).

Accessory components always make up less than $20 \%$ of the samples. They are composed of siliceous organisms, sponge spicules, nannofossils, unspecified carbonates, fish debris, and micronodules. Micronodules are more abundant in Samples 506C-3-2, 0-150 cm 507D-7-1, 16-21 cm, and 507D, 6-1, 12-22 cm, or they appear inside carbonate organisms (e.g., in Sample 507D-7-1, 16-21 cm) or clays (see Plate 2, Figs. 1, 6). An unidentified mineral which may be barite or a zeolite was also observed in Samples 506C-4-1, 121-125 cm (see Plate 2, Figs. 3-5) and 506C-3-1, 0-150 cm.

\section{MINERALOGY}

\section{METHODS}

The samples were studied by XRD in Strasbourg using air-dried, ethylene-glycol treated, and heated oriented smear slides of the $<2 \mu \mathrm{m}$ clay fractions $\left(\mathrm{Cu} \mathrm{K} \alpha\right.$ radiation, Ni filter, $40 \mathrm{kV} / 20 \mathrm{~mA}, 1^{\circ} 2 \theta$ per min., $0.1-1^{\circ}$ slits, from 2 to $30^{\circ} 2 \theta$ ), and air-dried randomly oriented powders of $<2 \mu \mathrm{m}$ fractions and bulk sediments ( $\mathrm{Cu} \mathrm{K} \alpha$ radiation, $\mathrm{Ni}$ 
Table 1. Bulk sediment sample sedimentology and X-ray diffraction.

\begin{tabular}{|c|c|c|c|c|}
\hline \multirow{2}{*}{$\begin{array}{c}\text { Sample } \\
\text { (intervals in } \mathrm{cm} \text { ) }\end{array}$} & \multirow{2}{*}{$\begin{array}{l}\text { Dry } \\
\text { Sediment } \\
\text { Color }\end{array}$} & \multicolumn{2}{|c|}{ Smear Slide Observations } & \multirow{2}{*}{$\begin{array}{c}\text { X-ray } \\
\text { Diffraction }\end{array}$} \\
\hline & & Clay Particle Morphology & Accessory Components & \\
\hline $506-6-2,39-41$ & $\begin{array}{l}\text { Bluish } \\
\text { grass- } \\
\text { green }\end{array}$ & $\begin{array}{l}\text { Olive green to pale brown; straight out- } \\
\text { lines; particles have birefringent edges; } \\
\text { variable size: Type } 1\end{array}$ & No & $\begin{array}{l}\text { Smectite } \\
\text { Trace of calcite }\end{array}$ \\
\hline $506-6-2,127-129$ & $5 Y 5 / 6$ & $\begin{array}{l}\text { Pale green, translucent; irregular outlines, } \\
\text { granular aggregates; variable size: Type } 2 \\
\text { (+ scarce Type } 1 \text { particles) }\end{array}$ & $5 \%$ Sponge spicules & $\begin{array}{l}\text { Smectite } \\
\text { Trace of calcite } \\
\text { Trace of barite? }\end{array}$ \\
\hline $506 \mathrm{C}-3-1,0-150$ & $\begin{array}{l}5 \mathrm{Y} 3 / 2 \\
+ \\
5 \mathrm{Y} 6 / 2\end{array}$ & $\begin{array}{l}\text { Olive green slab-shaped particles; straight } \\
\text { edges; variable size: Type } 3 \text { (+ scarce } \\
\text { Type } 2 \text { particles) }\end{array}$ & $\begin{array}{l}10 \% \text { unspecified carbonate }+ \text { fish } \\
\text { debris } \\
\text { Barite or zeolite crystals? }\end{array}$ & Smectite \\
\hline $506 \mathrm{C}-3-2,0-150$ & $5 Y 4 / 4$ & $\begin{array}{l}\text { Same as above, with numerous Type } 2 \\
\text { particles: Types } 3+\mathbf{2}\end{array}$ & $\begin{array}{l}20 \% \text { Fe-Mn micronodule frag- } \\
\text { ments } \\
10 \% \text { Carbonate organisms } \\
5 \% \text { Sponge spicules }+ \text { fish } \\
\text { debris }\end{array}$ & Smectite \\
\hline $506 C-3-3,93-113$ & $5 Y 5 / 6$ & $\begin{array}{l}\text { Pale green; granular aggregates; homo- } \\
\text { geneous size: Type } 2\end{array}$ & No & Smectite \\
\hline $506 C-4-1,121-125$ & $\begin{array}{l}5 Y 5 / 6 \\
\text { to } \\
5 Y 4 / 4\end{array}$ & $\begin{array}{l}\text { Green to brownish green granular aggre- } \\
\text { gates; diffuse outlines: Type } 2 \text { ( }+ \text { few } \\
\text { Type } 3 \text { particles) }\end{array}$ & $\begin{array}{l}5 \% \text { Unspecified carbonate }+ \\
\text { sponge spicules }+ \text { fish debris } \\
\text { Barite or zeolite crystals? }\end{array}$ & $\begin{array}{l}\text { Smectite } \\
\text { Trace of barite or harmotome? } \\
\text { Halite }\end{array}$ \\
\hline $506 C-4-2,122-126$ & $5 Y 4 / 4$ & $\begin{array}{l}\text { Grayish olive green granular aggregates; } \\
\text { small grains and slabs: Type } \mathbf{2}\end{array}$ & $\begin{array}{l}5 \% \text { Sponge spicules }+ \text { fish de- } \\
\text { bris + unspecified carbonate }\end{array}$ & $\begin{array}{l}\text { Smectite } \\
\text { Halite }\end{array}$ \\
\hline $506 C-4-3,53-57$ & $5 Y 5 / 4$ & $\begin{array}{l}\text { Dark olive green granular aggregates and } \\
\text { grains; irregular or straight outlines: } \\
\text { Types } 2+\mathbf{3} \text { (two distinct size popula- } \\
\text { tions) }\end{array}$ & $\begin{array}{l}10 \% \text { Sponge spicules }+ \text { fish de- } \\
\text { bris + unspecified carbonate }\end{array}$ & $\begin{array}{l}\text { Smectite } \\
\text { Halite } \\
\text { Trace of calcite, barite? }\end{array}$ \\
\hline 507D-6-1, 12-22 & $5 Y 5 / 6$ & $\begin{array}{l}\text { Yellow green to brown granular aggregates } \\
\text { and slabs: Types } 2 \text { and } 3+\text { watered } \\
\text { ("'moire") green }\end{array}$ & $\begin{array}{l}5 \% \text { Fe-Mn micronodule frag- } \\
\text { ments + fish debris + sponge } \\
\text { spicules }\end{array}$ & $\begin{array}{l}\text { Smectite } \\
\text { Calcite }\end{array}$ \\
\hline 507D-6-2, 37-41 & $5 Y 4 / 4$ & $\begin{array}{l}\text { Olive green granular aggregates: Type } 2 \\
\text { (+ scarce straight-edged slabs, Type } 1)\end{array}$ & No & Smectite \\
\hline $507 \mathrm{D}-6-2,90-130$ & $5 Y 4 / 3$ & $\begin{array}{l}\text { Pale olive green granular aggregates: Type } \\
2+\text { green homogeneous straight-edged } \\
\text { particles: Type } 1\end{array}$ & M S- & Smectite \\
\hline 507D-6-2, 103-107 & $5 Y 4 / 4$ & $\begin{array}{l}\text { Olive green to brown granular aggregates: } \\
\text { Type } 2\end{array}$ & $\begin{array}{l}5 \% \text { Sponge spicules }+ \text { unspec- } \\
\text { ified carbonate }+ \text { scarce oxides } \\
\text { inside carbonate fragments }\end{array}$ & Smectite \\
\hline 507D-7-1, 16-21 & $5 Y 4 / 4$ & $\begin{array}{l}\text { Dark olive green granular aggregates, slabs } \\
\text { and diffuse granules: Types } \mathbf{2}+\mathbf{3}\end{array}$ & $\begin{array}{l}10 \% \mathrm{Fe}-\mathrm{Mn} \text { micronodule frag- } \\
\text { ments + brown oxide grains; } \\
\text { scarce sponge spicules + fish } \\
\text { debris }\end{array}$ & Smectite \\
\hline
\end{tabular}

filter, $40 \mathrm{kV} 20 \mathrm{~mA}, 1^{\circ} 2 \theta$ per min., $0.1-1^{\circ}$ from 2 to $40^{\circ} 2 \theta$, and $4^{\circ}-.03-4^{\circ}$ slits from 40 to $65^{\circ} 2 \theta$ ). Five of the samples (Samples 5066-2, 39-41 cm, 506C-3-1, 0-150 cm, 506C-4-1, 121-125 cm, 506C-4-3, 53-57 cm, and 507D-6-2, 37-41 cm) were also studied by XRD in Miami using air-dried, ethylene-glycol treated, and heated oriented mounts prepared by aspiration of the $<2 \mu \mathrm{m}$ clay suspension onto $0.45 \mu \mathrm{m}$ silver filters (Cu K $\alpha$ radiation, Ni filter, $30 \mathrm{kV}, 25 \mathrm{~mA}, 1^{\circ} 2 \theta$ per min., $0.1-1^{\circ}$ slits, between 4 and $14^{\circ} 2 \theta$ ) with a Norelco-Phillips unit equipped with a graphite crystal monochromator. In addition, Samples 506C-3-1, 0-150 cm and 507D-6-2, 90-130 cm underwent further treatment: We attempted subdividing the $<2 \mu \mathrm{m}$ fractions into two or more grain-size fractions using a Sharpless ultracentrifuge. Several particle size limits were arbitrarily chosen between 2 and 0.4 $\mu \mathrm{m}$, and the fractions larger and smaller than these limits were observed with a transmission electron microscope (TEM) (Phillips EM 300 ), following the technique of Trauth et al. (1977). No morphological difference could be found between the particles forming the successive pairs (smaller and larger than the limit) fractions. XRD of the paired fractions using smear slides did not indicate any difference: Their clay mineralogies were similar to that of the bulk sample. As a consequence, the paired fractions were recombined before we attempted the next smaller particle size separation. The fraction larger than the chosen limit was always by far the smallest of the two by weight, and at the end the $<0.4 \mu \mathrm{m}$ fraction represented about $90 \%$ by weight of the initial $2 \mu \mathrm{m}$ sample.

\section{Isolated Clay Fractions}

XRD data and TEM observations of the $<2 \mu$ m clay fraction are summarized in Table 2 . All 13 samples display (060) d spacings ranging from 1.506 to $1.517 \AA$, indicating the dioctahedral nature of the clay minerals. This structure suggests that little $\mathrm{Mg}^{2+}$ or $\mathrm{Fe}^{2+}$ substitutes for $\mathrm{Fe}^{3+}$ in the octahedral sites. A transitional character between di- and trioctahedral structures had been noticed by Bischoff (1972) and Hoffert et al. (1978) for the hydrothermal clays of the Red Sea and FAMOUS area, respectively, and by Bentor and Kastner (1965) and Birch et al. (1976) for the glauconites of various localities. Other peaks corresponding to (020) and (004) d spacing are also generally present except in Samples 506C-3-3, 93-113 cm and 507D-6-2, 103-107 $\mathrm{cm}$, where the (004) peak is missing.

The presence of numerous well-defined peaks between 2 and $60^{\circ} 2 \theta$ indicate that the layers have not rotated about the $\mathrm{C}$ axis. About half of these peaks are asymmetrical, indicating that the stacking of the clay 
Table 2. d spacings $(\AA)$ of $<2 \mu$ m clay fraction after air drying, glycolation, and heating.

\begin{tabular}{|c|c|c|c|c|c|c|c|c|}
\hline \multirow{2}{*}{$\begin{array}{c}\text { Sample } \\
\text { (interval in } \mathrm{cm} \text { ) }\end{array}$} & \multicolumn{4}{|c|}{ Air-dried } & \multicolumn{2}{|c|}{ Glycolated } & \multirow{2}{*}{$\frac{\text { Heated }}{(001)}$} & \multirow[b]{2}{*}{ TEM Observations } \\
\hline & $(001)$ & (020) & $(004)$ & (060) & $(001)$ & $(001)+(002)$ & & \\
\hline $506-6-2,39-41$ & $\left\{\begin{array}{c}<11^{\mathrm{a}} \\
10.1+12.0\end{array}\right.$ & - & 3.25 & $1.515^{\mathrm{a}}$ & $18.0^{\mathrm{b}}$ & $\begin{array}{l}9.6+? 10 \\
9.8\end{array}$ & 9.8 & $\begin{array}{l}0.1-1.5 \mu \mathrm{m} \text { laths } \\
\text { (avg. }<0.5 \mu \mathrm{m} \text { ) }\end{array}$ \\
\hline $506-6-2,127-129$ & $11.7-13.3$ & 4.5 & 3.20 & $1.507-1.515^{\mathrm{a}}$ & 18.0 & $9.2-10$ & 10.0 & \\
\hline $506 \mathrm{C}-3-1,0-150$ & $12.5-14.0^{\mathrm{a}}$ & 4.45 & 3.25 & $1.514^{\mathrm{a}}$ & 18.0 & $9.0+? 10$ & 9.8 & $\begin{array}{l}\text { Mainly } 0.25-1.5 \mu \mathrm{m} \text { laths; } \\
\text { a few curl aggregates } \\
0.25-2 \mu \mathrm{m} \phi\end{array}$ \\
\hline $506 \mathrm{C}-3-2,0-150$ & $? 11.5+14.5$ & 4.4 & 3.25 & $1.509^{\mathrm{a}}$ & 17.0 & $9.2-9.6$ & $\begin{array}{l}9.8 \\
9.8\end{array}$ & \\
\hline $506 C-3-2,93-113$ & $12.8-13.9^{\mathrm{a}}$ & $4.9-4.6$ & - & $1.510^{\mathrm{a}}$ & 17.0 & $9.2-9.5$ & 10.0 & \\
\hline $506 \mathrm{C}-4-1,121-125$ & $\left\{\begin{array}{l}14.3-16.0 \\
14.1-15.0\end{array}\right.$ & 4.45 & 3.25 & $1.515^{\mathrm{a}}$ & $17.0-19.0$ & $\left\{\begin{array}{l}9.14 \\
8.8 \text { or } 9.0-9.5\end{array}\right.$ & 9.8 & $\begin{array}{l}\text { Mainly avg. } 0.5 \mu \mathrm{m} \text { laths; } \\
\text { a few curl aggregates } \\
1 \mu \mathrm{m} \phi\end{array}$ \\
\hline $506 \mathrm{C}-4-2,122-126$ & $13.0-15.0$ & 4.5 & 3.20 & $1.512^{\mathrm{a}}$ & 17.0 & 9.0 & 10.0 & \\
\hline $506 C-4-3,53-57$ & 14.0 & 4.5 & 3.30 & $1.508^{\mathrm{a}}$ & 18.0 & $9.2-9.8$ & 9.8 & \\
\hline 507D-6-1, 12-22 & $13.6-14.5$ & 4.5 & 3.25 & 1.511 & $17.0-18.0$ & $8.9-9.3$ & 9.8 & \\
\hline $507 \mathrm{D}-6-2,37-41$ & $12.0-14.0$ & 4.5 & 3.20 & $1.511^{\mathrm{a}}$ & $17.0-18.0$ & $9.1+10.2$ & 10.0 & $\begin{array}{l}\text { Mainly } 0.1-1.5 \mu \text { m laths; } \\
\text { few curl aggregates }\end{array}$ \\
\hline $507 \mathrm{D}-6-2,90-130$ & $14.5^{\mathrm{a}}$ & 4.5 & 3.20 & $1.517^{\mathrm{a}}$ & 17.5 & 9.2 & 9.8 & $\begin{array}{l}\text { Mainly } 0.25-1.5 \mu \mathrm{m} \text { laths; } \\
\text { a few curl aggregates } \\
0.25-2 \mu \mathrm{m} \phi\end{array}$ \\
\hline $507 \mathrm{D}-6-2,103-107$ & $11.5-12.5^{\mathrm{a}}$ & 4.5 & - & 1.510 & 17.0 & $8.9-9.3$ & 9.8 & $\begin{array}{l}\text { Mainly } 0.1-0.25 \mathrm{~m} \text { laths; } \\
\text { few curl aggregates }\end{array}$ \\
\hline 507D-7-1, 16-21 & 12.8 & 4.45 & 3.20 & 1.512 & 17.0 & $9.2-9.8$ & 10.0 & \\
\hline
\end{tabular}

Note: $+=$ two independent peaks; $-=$ (from ...to...): broad peak.

a Asymmetrical peak.

b No peak but concave "bump" between 15 and $20 \AA$.

layers along the $\mathrm{C}$ axis is not perfectly ordered (translation along $\mathrm{b}$ axis).

The position of the (001) d spacings corresponding to the basal plane of the clay minerals deserves special attention. The (001) d spacings of most air-dried samples of clay fractions are generally broad, ranging from 11.5 to $16.0 \AA$. The $(001) \mathrm{d}$ spacings generally expand to 17 to $18 \AA$ upon glycolation and collapse to 9.8 to $10 \AA$ after heating. These observations indicate that the clay fractions are essentially made up of mixed-layer smectite $[(001)$ air dried at $\sim 14 \AA$, expanding up to $\sim 17 \AA$ and collapsing to $\sim 10 \AA]$-mica $[(001)$ air dried at $\sim 10$ $\AA$, which does not expand or collapse] minerals. The lack of multiple $d$ spacings at $24 \AA$, etc. indicates that the clays are not regular mixed-layer minerals. However, Sample 507D-6-2, 37-41 cm (and possibly Sample 506C-3-1, 0-150 cm) displays, upon glycolation, an expanded smectite (001) d spacing peak at about $18 \AA$, a combined smectite (002)-mica (001) d spacing peak at about $9 \AA$, and another peak at about $10 \AA$ corresponding to the (001) spacing of mica. The latter could indicate the presence of mica particles in addition to the mixed-layer smectite-mica particles making up the majority of the samples.

The only exception is Sample 506-6-2, 39-41 cm, either because its air-dried (001) d spacing peak is located at slightly less than $11 \AA$ (XRD made in Strasbourg), or because the sample displays two peaks: at $10.1 \AA$ (the highest) and $12.0 \AA$ (XRD made in Miami). Upon glycolation either of the two peaks clearly appears at 18 and $9.6 \AA$-possibly with a third (smaller) one at $10 \AA$ (XRD made in Strasbourg) - or one peak appears at $9.8 \AA$ and a convex "bump" appears from about 18 to $20 \AA$ (XRD made in Miami). After heating, the (001) d spacing collapses to $9.8 \AA$. The location of an airdried $(001) \mathrm{d}$ spacing at 10 or $11 \AA$, the intensity of the combined smectite (002)-mica (001) d spacings at 9.6 or $9.8 \AA$, and the possible presence of an independent mica (001) peak at $10 \AA$ upon glycolation indicate that this sample is by far the richest in mica.

The same sample is also unique from several other points of view. It is one of the most potassic, with $5.31 \%$ $\mathrm{K}_{2} \mathrm{O}$ by weight (recalculated on a water-free basis) or $0.458 \mathrm{~K}$ in the structural formula (calculated on the basis of 22 charges). However, Sample 506-6-2, 127-129 $\mathrm{cm}$ is as potassic, with $5.33 \% \mathrm{~K}_{2} \mathrm{O}$ or $0.462 \mathrm{~K}$ in the formula, even though its X-ray diffractogram does not present the mica features as in Sample 506-6-2, 39-41 cm. It is the only sample which when dried displays a bluish grass-green color which is not included as a reference in the Faber and Castel Color Chart of Soils and Sediments; the color of other dried samples varies from 5Y5/ 6 , to $5 \mathrm{Y} 5 / 5$, to $5 \mathrm{Y} 5 / 4$, to $5 \mathrm{Y} 3 / 2$, to $5 \mathrm{Y} 4 / 3$, to $5 \mathrm{Y} 6 / 2$. It is the only sample which appears in smear slides to be made up solely of morphological Type 1 particles. With the TEM it appears to be made up of laths only, without any flakes or "curls" (see TEM observations, Table 2). Finally, it was the last sample to floculate when suspended in distilled water (about $11 / 2$ days after the others).

On the other hand, Sample 506C-4-1, 121-125 cm seems to be the most smectitic because after glycolation a (002) d spacing peak of smectite sometimes appears at $8.8 \AA$, in addition to the combined smectite (002)-mica (001) d spacing at 9.2 to $9.5 \AA$. This sample appears with the TEM to be the richest in flakes and "curls," 
and in smear slide to be deprived of morphological Type 1 particles. Finally, it has the highest $\mathrm{Al}$ content (see "'Geochemistry").

Most of the clay fraction samples when observed with the TEM (Table 2) appear to be made up predominantly of lath-shaped clay particles, ranging from 0.1 to $1.5 \mu \mathrm{m}$ in length, with most less than $0.5 \mu \mathrm{m}$ long. Longer "curled"' flakes are also observed, but are never abundant. They often form irregular or ball-shaped aggregates, ranging from 0.25 to $2.5 \mu \mathrm{m}$ in diameter.

\section{Bulk Sediment Samples}

X-ray diffractions of bulk sediment samples allowed us to identify some of the accessory components such as calcite, and halite which is thought to have precipitated from the sediment pore water as a result of our drying the samples in the laboratory. Unfortunately the Fe-Mn oxides and the unidentified minerals (barite or zeolite?) in Sample 506C-4-1, 121-125 cm could not be identified because of their poor crystallinity and/or small proportion. The diffractograms clearly indicate that the clay mineral(s) is (are) overwhelmingly the major component of the bulk sediment samples. They also confirm the dioctahedral structure of the clays.

In summary, study of both isolated clay fractions and bulk sediment samples demonstrates the complexity of the clay mineralogy of the hydrothermal clay layers of the Galapagos mounds. However, one must keep in mind that five of our samples were collected from sections varying from 59 to $150 \mathrm{~cm}$ in length and could very well represent mixtures of otherwise more homogeneous clay layers.

\section{GEOCHEMISTRY}

\section{Major Element Geochemistry}

The geochemical data are derived from the same set of samples studied above. Major and trace element analyses were performed following the method described by Besnus and Lucas (1968) and Besnus and Rouault (1973), using arc spectrometry and an ARL quantometer. The method consists of melting the sample in a mixture of lithium tetraborate and introducing the melt into a glycolated solvent. Trace elements were determined using the inductive-coupled plasma technique (ICP -35000C-ARL).

$\mathrm{Na}$ and $\mathrm{K}$ were determined by emission spectrometry. Relative precision is $\pm 2 \%$ for major elements and $\pm 10 \%$ for trace elements.

Geochemical data are presented in Tables 3 to 6 . Chemical analyses were recalculated taking mineralogical information into consideration in order to compare bulk sediment to the isolated clay fraction (see Tables 7 , 8 ). We ascribed the $\mathrm{CaO}$ content to carbonate organisms, and we eliminated the $\mathrm{Na}_{2} \mathrm{O}$ content since it most likely results from the presence of halite which precipitated from the pore waters. The low $\mathrm{TiO}_{2}$ contents were not considered either.

The major element compositions of bulk sediment samples and isolated clay fractions are compared in the correlation diagrams of Fig. 2A to 2F. Two main groups of samples can be defined, and the element distribution between bulk sediments (i.e., the large clay particles) and the corresponding $<2 \mu \mathrm{m}$ fractions can be studied. There is little chemical difference between the bulk sediment samples (including clay minerals $+\mathrm{Fe}-\mathrm{Mn}$ oxides + siliceous organisms + other silicates) and the $<2 \mu \mathrm{m}$ fraction (presumably clay minerals alone) because the hydrothermal sediments are essentially made up of Ferich, $\mathrm{Al}-$ and $\mathrm{Mg}$-poor clay minerals. When the $\mathrm{SiO}_{2}$ content is higher in the bulk sediment than in the clay fraction, as in Sample 506-6-2, 127-129 cm, one can assume that it is the result of the presence of siliceous organisms or silicates $>2 \mu \mathrm{m}$ which were often observed in smear slides. On the other hand, when $\mathrm{SiO}_{2}$ content is higher in the clay fraction than in the bulk sediment, this enrichment must be the result of the composition of the clay minerals themselves, since no colloidal silica debris was observed during cursory observation of the samples studied with TEM. The MgO contents of bulk and $<2 \mu \mathrm{m}$ fraction samples are similar and vary little among different samples. $\mathrm{K}_{2} \mathrm{O}$ contents are generally small in both the bulk samples and clay fractions; exceptions are in Samples 506-6-2, 39-41 cm and 127-129 cm, where, recalculated on a water-free basis, $\mathrm{K}_{2} \mathrm{O}$ contents are, respectively, 5.31 and $5.9 \%$ (in the $<2 \mu \mathrm{m}$ fraction and bulk sediments), and 5.33 and $3.37 \%$ (in the $<2 \mu \mathrm{m}$ fraction and bulk sediments), where the $<2 \mu \mathrm{m}$ fractions are much richer in $\mathrm{K}$ than the corresponding bulk sediment samples.

$\mathrm{Al}_{2} \mathrm{O}_{3}$ contents are always very low, but three clay fractions contain much more aluminum than the corresponding bulk sediments. Bulk sediment samples always have higher total iron (recalculated as $\mathrm{Fe}_{2} \mathrm{O}_{3}$ ) contents than the $<2 \mu \mathrm{m}$ fractions. This results from the presence of $\mathrm{Fe}-\mathrm{Mn}$ oxides in the coarse fraction, particularly in Samples 506-6-2, 39-41 cm and 507D-7-1, 16-21 $\mathrm{cm}$, where micronodules were observed. The same samples also have high $\mathrm{SiO}_{2}$ contents. It appears that the formation of iron oxides next to the clays is favored when the clay fraction is more siliceous and does not admit any more iron. The $\mathrm{Mn}_{3} \mathrm{O}_{4}$ contents of bulk sediments and clay fractions are generally almost identical. However, in Samples 506C-4-5, 53-57 cm and 506C-3-2, $0-150 \mathrm{~cm}$, manganese is present as oxides in micronodules and debris $>2 \mu \mathrm{m}$, giving the bulk sediment a higher Mn content. On the other hand, manganese is more abundant in the clay fraction of Samples 507D$6-2,103-107 \mathrm{~cm}$ and $507 \mathrm{D}-7-1,16-21 \mathrm{~cm}$. It is therefore seen that iron and manganese, generally found together as hydroxides, are in this case differentiated by the particle sizes: Manganese is often related to the finest particles, whereas iron is found in the coarser ones. The micronodules are essentially made up of manganese oxides coating carbonate organism debris.

This comparison between the major element compositions of the clay fractions and corresponding bulk samples (excluding $\mathrm{CaO}$ ) allows us to distinguish two major groups of clays which have in common the moreor-less magnesian chemistry of Fe-rich clay minerals. The first group comprises the more aluminous clay minerals, and the second the more potassic clay minerals. 
Table 3. Chemical analyses of bulk hydrothermal sediments from Leg 70, Holes 506, 506C and 507D.

\begin{tabular}{|c|c|c|c|c|c|c|c|c|c|c|c|c|c|}
\hline $\begin{array}{c}\text { Sample } \\
\text { (interval in } \mathrm{cm} \text { ) }\end{array}$ & $\mathrm{SiO}_{2}$ & $\mathrm{Al}_{2} \mathrm{O}_{3}$ & $\mathrm{MgO}$ & $\mathrm{CaO}$ & \multicolumn{2}{|c|}{ (wt. \%) } & $\mathrm{Mn}_{3} \mathrm{O}_{4}$ & $\mathrm{TiO}_{2}$ & $\mathrm{BaO}$ & $\mathrm{Na}_{2} \mathrm{O}$ & $\mathrm{K}_{2} \mathrm{O}$ & LOI & Total \\
\hline $506-6-2,39-41$ & 52.0 & $<0.2$ & 4.39 & $<0.2$ & 21.3 & 9.8 & 0.051 & $<0.02$ & 0.01 & 0.63 & 5.58 & 5.13 & 100.14 \\
\hline $506-6-2,127-129$ & 54.0 & $<0.2$ & 4.70 & $<0.2$ & 18.7 & 9.5 & 0.080 & $<0.02$ & 0.02 & 1.92 & 3.08 & 6.22 & 99.56 \\
\hline $506 \mathrm{C}-3-2,0-150$ & 53.4 & 0.4 & 4.07 & 0.4 & 26.0 & 3.0 & 0.413 & $<0.02$ & 0.05 & 2.29 & 3.66 & 6.33 & 100.28 \\
\hline $506 \mathrm{C}-3-1,0-150$ & 53.7 & 0.4 & 4.04 & 0.3 & 25.8 & 4.3 & 0.182 & 0.03 & 0.04 & 1.88 & 3.77 & 5.83 & 100.72 \\
\hline $506 C-3-3,93-113$ & 53.0 & 0.3 & 4.36 & 0.3 & 23.1 & 5.9 & 0.057 & 0.02 & 0.05 & 2.48 & 3.54 & 6.49 & 100.03 \\
\hline $506 \mathrm{C}-4-1,121-125$ & 52.4 & 1.0 & 4.18 & 0.4 & 24.2 & 3.6 & 0.047 & 0.05 & 0.12 & 3.99 & 2.34 & 8.18 & 100.84 \\
\hline $506 C-4-2,122-126$ & 51.3 & 0.6 & 4.20 & 0.5 & 23.0 & 4.9 & 0.047 & 0.03 & 0.12 & 3.40 & 2.88 & 7.77 & 99.39 \\
\hline $506 \mathrm{C}-4-3,53-57$ & 51.4 & 0.6 & 4.53 & 0.4 & 24.9 & 3.4 & 0.053 & 0.02 & 0.10 & 3.83 & 2.66 & 8.14 & 100.40 \\
\hline 507D-6-1, 12-22 & 53.2 & 0.3 & 3.48 & 0.6 & 29.2 & 1.8 & 0.188 & $<0.02$ & 0.04 & 2.49 & 2.50 & 6.47 & 100.36 \\
\hline 507D-6-2, 37-41 & 51.7 & $<0.2$ & 4.87 & 0.3 & 22.6 & 5.5 & 0.065 & $<0.02$ & $<0.01$ & 2.77 & 3.30 & 6.78 & 98.48 \\
\hline $507 \mathrm{D}-6-2,103-107$ & 53.5 & 0.3 & 4.83 & 0.2 & 22.9 & 6.1 & 0.039 & $<0.02$ & 0.02 & 2.25 & 3.26 & 6.19 & 100.26 \\
\hline 507D-6-2, 90-130 & 52.8 & 0.2 & 4.66 & 0.3 & 23.0 & 5.5 & 0.048 & $<0.02$ & 0.01 & 2.97 & 3.07 & 7.04 & 100.21 \\
\hline $507 \mathrm{D}-7-1,16-21$ & 51.7 & 0.3 & 3.51 & 0.8 & 30.4 & 2.9 & 0.267 & $<0.02$ & 0.03 & 1.77 & 2.45 & 6.00 & 100.34 \\
\hline \multicolumn{14}{|c|}{$\mathrm{Fe}_{2} \mathrm{O}_{3}$ Total } \\
\hline $\mathrm{m}$ & 52.6 & 0.38 & 4.3 & 0.37 & & 29.9 & & $0 . c(-x)-x)$ & 0. & 2. & 3.2 & 6.66 & 100.11 \\
\hline$\sigma$ & 0.9 & 0.23 & 0.45 & 0.17 & & 1.6 & 0.114 & 0.08 & 0.04 & 0.91 & 0.84 & 0.91 & - \\
\hline
\end{tabular}

Note: Total iron was calculated as $\mathrm{Fe}_{2} \mathrm{O}_{3}$ and total manganese as $\mathrm{Mn}_{3} \mathrm{O}_{4} ; \mathrm{m}=$ mean; $\sigma=$ deviation; ${ }^{*}=$ total of the mean values.

Table 4. Trace element concentrations of bulk hydrothermal sediments from Leg 70, Holes 506, 506C, and 507D.

\begin{tabular}{llrrrrrrr}
\hline $\begin{array}{c}\text { Sample } \\
\text { (interval in cm) }\end{array}$ & Sr & Ba & $\begin{array}{c}\mathrm{V} \\
\text { Ni } \\
\text { (ppm) }\end{array}$ & Cr & $\mathrm{Zn}$ & $\mathrm{Cu}$ & $\mathrm{Zr}$ \\
\hline 506-6-2, 39-41 & 20 & 141 & 8 & - & 7 & 61 & 14 & 7 \\
$506-6-2,127-129$ & 22 & 163 & 14 & - & 8 & 28 & 12 & 8 \\
506C-3-2, 0-150 & 60 & 385 & 13 & - & 17 & 24 & 29 & 14 \\
506C-3-1, 0-150 & 46 & 264 & 11 & - & 8 & 31 & 23 & 8 \\
506C-3-3, 93-113 & 44 & 397 & 9 & 22 & 9 & 29 & 14 & 9 \\
506C-4-1, 121-125 & 84 & 1115 & 23 & 14 & 27 & 28 & 18 & 17 \\
506C-4-2, 122-126 & 80 & 1110 & 21 & 11 & 25 & 35 & 64 & 11 \\
506C-4-3, 53-57 & 69 & 900 & 9 & - & 25 & 39 & 19 & 8 \\
507D-6-1, 12-22 & 54 & 313 & 12 & - & 6 & 35 & 21 & 8 \\
507D-6-2, 37-41 & 33 & 56 & 6 & - & 6 & 38 & 8 & 7 \\
507D-6-2, 103-107 & 32 & 173 & 7 & 8 & 6 & 31 & 9 & 12 \\
507D-6-2, 90-130 & 35 & 163 & 12 & - & 33 & 30 & 20 & 9 \\
507D-7-1, 16-21 & 58 & 240 & 14 & 8 & 12 & 48 & 12 & 14 \\
\multicolumn{1}{c}{ m } & 49 & 350 & 12 & - & 14 & 35 & 20 & 10 \\
\multicolumn{1}{c}{$\sigma$} & 20 & 373 & 5 & - & 9 & 10 & 14 & 3 \\
\hline
\end{tabular}

Note: $-=$ undetermined element; $\mathrm{m}=$ mean; $\sigma=$ deviation.

Table 5. Chemical analyses of the clay fraction $(<2 \mu \mathrm{m})$ of hydrothermal sediments from Leg 70, Holes 506, 506C, and 507D.

\begin{tabular}{|c|c|c|c|c|c|c|c|c|c|c|c|c|}
\hline $\begin{array}{c}\text { Sample } \\
\text { (interval in } \mathrm{cm} \text { ) }\end{array}$ & $\mathrm{SiO}_{2}$ & $\mathrm{Al}_{2} \mathrm{O}_{3}$ & $\mathrm{MgO}$ & $\mathrm{CaO}$ & $\mathrm{Fe}_{2} \mathrm{O}_{3}$ & $\begin{array}{l}\mathrm{Mn}_{3} \mathrm{O}_{4} \\
\text { (wt. } \% \text { ) }\end{array}$ & $\mathrm{TiO}_{2}$ & $\mathrm{BaO}$ & $\mathrm{Na}_{2} \mathrm{O}$ & $\mathrm{K}_{2} \mathrm{O}$ & LOI & Total \\
\hline $506-6-2,39-41$ & 53.0 & 0.4 & 4.67 & 0.5 & 28.7 & 0.054 & $<0.02$ & 0.03 & 0.46 & 4.87 & 5.42 & 98.15 \\
\hline $506-6-2,127-129$ & 53.2 & 0.3 & 5.04 & 0.4 & 30.9 & 0.075 & $<0.02$ & 0.01 & 0.59 & 5.04 & 5.08 & 100.60 \\
\hline $506 C-3-2,0-150$ & 53.5 & 1.1 & 4.11 & 1.0 & 28.6 & 0.240 & 0.05 & 0.08 & 0.71 & 2.61 & 6.14 & 98.20 \\
\hline $506 \mathrm{C}-3-1,0-150$ & 54.6 & 0.5 & 4.03 & 0.3 & 29.3 & 0.368 & 0.02 & 0.04 & 0.71 & 3.36 & 5.39 & 98.63 \\
\hline $506 C-3-3,93-113$ & 54.7 & 0.5 & 4.65 & 0.5 & 29.2 & 0.055 & 0.03 & 0.06 & 0.72 & 2.87 & 5.23 & 98.49 \\
\hline $506 \mathrm{C}-4-1,121-125$ & 54.0 & 2.3 & 4.66 & 0.7 & 28.8 & 0.076 & 0.08 & 0.18 & 0.69 & 2.16 & 5.61 & 99.18 \\
\hline $506 C-4-2,122-126$ & 55.2 & 1.1 & 4.77 & 0.5 & 30.3 & 0.065 & 0.05 & 0.16 & 0.76 & 2.53 & 5.58 & 100.99 \\
\hline $506 C-4-3,53-57$ & 55.2 & 0.4 & 4.76 & 0.3 & 30.1 & 0.061 & $<0.02$ & 0.07 & 0.52 & 2.55 & 5.73 & 99.79 \\
\hline 507D-6-1, 12-22 & 55.6 & 0.3 & 3.57 & 1.2 & 31.4 & 0.058 & $<0.02$ & 0.03 & 0.59 & 2.08 & 5.89 & 100.69 \\
\hline 507D-6-2, 37-41 & 55.9 & $<0.2$ & 5.04 & 0.3 & 30.4 & 0.058 & $<0.02$ & $<0.01$ & 0.40 & 3.03 & 5.18 & 100.50 \\
\hline $507 \mathrm{D}-6-2,103-107$ & 54.1 & 0.5 & 4.95 & 0.3 & 30.3 & 0.042 & 0.02 & 0.02 & 0.77 & 3.13 & 5.28 & 99.34 \\
\hline $507 \mathrm{D}-6-2,90-130$ & 56.0 & 0.3 & 4.90 & 0.5 & 30.2 & 0.065 & $<0.02$ & 0.02 & 0.26 & 2.88 & 5.72 & 100.82 \\
\hline 507D-7-1, 16-21 & 54.1 & 0.4 & 3.69 & 1.8 & 29.3 & 0.310 & 0.02 & 0.02 & 0.66 & 2.24 & 6.47 & 99.00 \\
\hline $\mathrm{m}$ & 54.5 & 0.6 & 4.52 & 0.6 & 29.8 & 0.117 & 0.03 & 0.05 & 0.56 & 2.98 & 5.59 & 99.34* \\
\hline$\sigma$ & 0.9 & 0.5 & 0.50 & 0.4 & 0.9 & 0.110 & 0.02 & 0.05 & 0.22 & 0.96 & 0.96 & - \\
\hline
\end{tabular}

Note: Total iron was calculated as $\mathrm{Fe}_{2} \mathrm{O}_{3}$ and total manganese as $\mathrm{Mn}_{3} \mathrm{O}_{4} ;<=$ value below the lower detection limit; $\mathrm{m}=$ mean; $\sigma=$ deviation; ${ }^{*}=$ total of the mean values. 
Table 6. Trace-element concentrations of clay fraction $(<2 \mu \mathrm{m})$ of the hydrothermal sediments from Leg 70, Holes 506, 506C, and 507D.

\begin{tabular}{lrrcccccc}
\hline $\begin{array}{c}\text { Sample } \\
\text { (interval in cm) }\end{array}$ & $\mathrm{Sr}$ & $\mathrm{Ba}$ & $\mathrm{V}$ & $\begin{array}{c}\mathrm{Ni} \\
\text { (ppm) }\end{array}$ & $\mathrm{Cr}$ & $\mathrm{Zn}$ & $\mathrm{Cu}$ & $\mathrm{Zr}$ \\
\hline 506-6-2, 39-41 & 48 & 367 & 12 & - & 17 & 44 & 87 & 14 \\
506-6-2, 127-129 & 43 & 187 & 17 & - & 17 & 68 & 94 & 15 \\
506C-3-2, 0-150 & 109 & 839 & 25 & - & 38 & 71 & 85 & 19 \\
506C-3-1, 0-150 & 56 & 558 & 16 & - & 73 & 45 & 61 & 14 \\
506C-3-3, 93-113 & 69 & 701 & 18 & 41 & 27 & 54 & 87 & 12 \\
506C-4-1, 121-125 & 114 & 2128 & 59 & 83 & 44 & 118 & 142 & 22 \\
506C-4-2, 122-126 & 96 & 1647 & 46 & 51 & 58 & 82 & 118 & 18 \\
506C-4-3, 53-57 & 48 & 754 & 16 & - & 15 & 28 & 45 & 11 \\
507D-6-1, 12-22 & 79 & 406 & 25 & - & 16 & 45 & 30 & 14 \\
507D-6-2, 37-41 & 40 & 81 & 15 & - & 16 & 48 & 38 & 14 \\
507D-6-2, 103-107 & 30 & 218 & 15 & 49 & 32 & 27 & 49 & 15 \\
507D-6-2, 90-130 & 50 & 196 & 19 & - & 11 & 49 & 30 & 12 \\
507D-7-1, 16-21 & 110 & 208 & 22 & 23 & 15 & 48 & 33 & 14 \\
\multicolumn{1}{c}{ m } & 69 & 637 & 23 & - & 29 & 55 & 69 & 15 \\
\multicolumn{1}{c}{$\sigma$} & 29 & 611 & 14 & - & 19 & 23 & 36 & 31 \\
\hline
\end{tabular}

Note: $-=$ undetermined element; $\mathrm{m}=$ mean; $\sigma=$ deviation.

Table 7. Chemical data of hydrothermal sediments (bulk sediment) recalculated for $\mathrm{SiO}_{2}+\mathrm{Al}_{2} \mathrm{O}_{3}+\mathrm{MgO}+\mathrm{Fe}_{2} \mathrm{O}_{3}+\mathrm{Mn}_{3} \mathrm{O}_{4}+\mathrm{K}_{2} \mathrm{O}$ $=100$.

\begin{tabular}{lcccccc}
\hline $\begin{array}{c}\text { Sample } \\
\text { (interval in cm) }\end{array}$ & $\mathrm{SiO}_{2}$ & $\mathrm{Al}_{2} \mathrm{O}_{3}$ & $\mathrm{MgO}$ & $\mathrm{Fe}_{2} \mathrm{O}_{3}$ & $\mathrm{Mn}_{3} \mathrm{O}_{4}$ & $\mathrm{~K}_{2} \mathrm{O}$ \\
\hline 506-6-2, 39-41 & 55.1 & 0.21 & 4.65 & 34.1 & 0.054 & 5.90 \\
506-6-2, 127-129 & 59.1 & 0.22 & 5.14 & 32.0 & 0.087 & 3.37 \\
506C-3-2, 0-150 & 58.5 & 0.44 & 4.46 & 32.1 & 0.452 & 4.01 \\
506C-3-1, 0-150 & 57.9 & 0.43 & 4.36 & 33.0 & 0.196 & 4.06 \\
506C-3-3, 93-113 & 58.4 & 0.33 & 4.80 & 32.7 & 0.063 & 3.68 \\
506C-4-1, 121-125 & 59.4 & 1.13 & 4.73 & 32.0 & 0.053 & 2.65 \\
506C-4-2, 122-126 & 58.5 & 0.68 & 4.89 & 32.5 & 0.054 & 3.28 \\
506C-4-3, 53-57 & 58.4 & 0.68 & 5.15 & 32.6 & 0.060 & 3.02 \\
507D-6-1, 12-22 & 58.5 & 0.33 & 3.83 & 34.3 & 0.207 & 2.75 \\
507D-6-2, 37-41 & 58.2 & 0.22 & 5.48 & 32.3 & 0.073 & 3.71 \\
507D-6-2, 103-107 & 58.4 & 0.33 & 5.27 & 32.4 & 0.043 & 3.55 \\
507D-6-2, 90-130 & 58.7 & 0.22 & 5.18 & 32.4 & 0.053 & 3.41 \\
507D-7-1, 16-21 & 56.3 & 0.33 & 3.82 & 36.6 & 0.291 & 2.67 \\
\multicolumn{1}{c}{$\sigma$} & 58.1 & 0.42 & 4.75 & 33.0 & 0.129 & 3.54 \\
$\sigma$ & 1.1 & 0.26 & 0.52 & 13.0 & 0.124 & 0.83 \\
\hline
\end{tabular}

Note: $\mathrm{m}=$ mean; $\sigma=$ deviation.
This distinction is even more noticeable in the isolated clay fractions.

Figure 3 schematically illustrates the distribution of the major and trace elements between the main mineral components forming the green clays of the Galapagos mounds. Note the following:

1) Fe occurs in both the clay minerals, where it is associated with $\mathrm{Si}$, and the oxides, where it is associated with Mn.

2) The framework of the clay minerals is formed by $\mathrm{Si}-\mathrm{Fe}$, and a differentiation exists between a K-rich and an $\mathrm{Al}, \mathrm{Mg}$-rich end member.

3) Siliceous and carbonate organisms are a secondary source of elements.

Geochemical differentiations among hydrothermal smectites are derived from calculating structural formulas. Structural formulas (see Table 9) were calculated with the assumption that all of the iron is present in its ferric state and eliminating excess $\mathrm{Mn}$ (i.e., $\mathrm{Mn}_{3} \mathrm{O}_{4}>$ $0.07 \%$ ), plus all of the calcium, sodium, and titanium. Actually we know that the assumption is not true, since from 1.8 to $9.8 \%$ FeO was analyzed in the bulk sediment samples. Structural formulas confirm the essentially dioctahedral nature of the hydrothermal clays. As with the chemical distinction based on the major element contents of the clay mineral fraction, one can distinguish two major groups of clay minerals according to their formulas:

1) A "nontronitic" group comprises those samples which have the higher $\mathrm{Al}$ content, indicating the possibility of a slight substitution of $\mathrm{Al}$ in the tetrahedral sites. High Al contents are negatively correlated with low $\mathrm{MgO}$ contents. $\mathrm{K}_{2} \mathrm{O}$ contents are small. Sample $506 \mathrm{C}-4-1,121-125 \mathrm{~cm}$ is the most representative example of this type.

2) A "celadonitic" group comprises the most potassic samples, which are also the richest in iron and silica.

Relationships between these two groups appear clearly in the ternary diagrams $\mathrm{Fe}_{2} \mathrm{O}_{3}-\mathrm{Al}_{2} \mathrm{O}_{3}-\mathrm{K}_{2} \mathrm{O}$ (Fig. 4).

Table 8. Chemical data of clay fraction $(<2 \mu \mathrm{m})$ of hydrothermal sediments recalculated for $\mathrm{SiO}_{2}+\mathrm{Al}_{2} \mathrm{O}_{3}+\mathrm{MgO}$ $+\mathrm{Fe}_{2} \mathrm{O}_{3}+\mathrm{Mn}_{3} \mathrm{O}_{4}+\mathrm{K}_{2} \mathrm{O}=100$.

\begin{tabular}{|c|c|c|c|c|c|c|c|c|c|c|}
\hline $\begin{array}{c}\text { Sample } \\
\text { (interval in } \mathrm{cm} \text { ) }\end{array}$ & $\mathrm{SiO}_{2}$ & $\mathrm{Al}_{2} \mathrm{O}_{3}$ & $\mathrm{MgO}$ & $\mathrm{Fe}_{2} \mathrm{O}_{3}$ & $\mathrm{Mn}_{3} \mathrm{O}_{4}$ & $\mathrm{~K}_{2} \mathrm{O}$ & $\frac{\mathrm{SiO}_{2}}{\mathrm{Al}_{2} \mathrm{O}_{3}}$ & $\frac{\mathrm{SiO}_{2}}{\mathrm{Fe}_{2} \mathrm{O}_{3}}$ & $\frac{\mathrm{Fe}_{2} \mathrm{O}_{3}}{\mathrm{MgO}}$ & $\frac{\mathrm{Fe}_{2} \mathrm{O}_{3}}{\mathrm{~K}_{2} \mathrm{O}}$ \\
\hline $506-6-2,39-41$ & 57.8 & 0.43 & 5.09 & 31.3 & 0.059 & 5.31 & 134 & 1.84 & 6.15 & 5.9 \\
\hline $506-6-2,127-129$ & 56.2 & 0.32 & 5.33 & 32.6 & 0.079 & 5.33 & 175 & 1.72 & 6.11 & 6.1 \\
\hline $506 C-3-2,0-150$ & 59.3 & 1.22 & 4.55 & 31.7 & 0.266 & 2.89 & 48 & 1.87 & 6.96 & 10.9 \\
\hline $506 C-3-1,0-150$ & 59.2 & 0.54 & 4.37 & 31.8 & 0.399 & 3.64 & 109 & 1.86 & 7.27 & 8.7 \\
\hline $506 C-3-3,93-113$ & 59.4 & 0.54 & 5.05 & 31.7 & 0.059 & 3.12 & 110 & 1.87 & 6.28 & 10.1 \\
\hline $506 \mathrm{C}-4-1,121-125$ & 58.7 & 2.50 & 5.06 & 31.3 & 0.082 & 2.35 & 23 & 1.87 & 6.18 & 13.3 \\
\hline $506 \mathrm{C}-4-2,122-126$ & 58.7 & 1.17 & 5.06 & 32.2 & 0.069 & 2.69 & 50 & 1.82 & 6.36 & 11.9 \\
\hline $506 C-4-3,53-57$ & 59.3 & 0.43 & 5.11 & 32.3 & 0.065 & 2.74 & 138 & 1.83 & 6.32 & 11.8 \\
\hline 507D-6-1, 12-22 & 59.8 & 0.32 & 3.83 & 33.7 & 0.062 & 2.23 & 186 & 1.77 & 8.80 & 15.1 \\
\hline 507D-6-2, 37-41 & 58.6 & 0.21 & 5.37 & 32.4 & 0.062 & 3.23 & 279 & 1.81 & 6.03 & 10.0 \\
\hline 507D-6-2, 103-107 & 58.1 & 0.54 & 5.32 & 32.5 & 0.045 & 3.36 & 107 & 1.79 & 6.11 & 9.6 \\
\hline 507D-6-2, 90-130 & 59.3 & 0.32 & 5.19 & 32.0 & 0.069 & 3.05 & 185 & 1.85 & 6.16 & 10.5 \\
\hline $507 \mathrm{D}-7-1,16-21$ & 60.1 & 0.44 & 4.09 & 32.5 & 0.344 & 2.49 & 136 & 1.85 & 7.94 & 13.0 \\
\hline $\mathrm{m}$ & 58.8 & 0.69 & 4.88 & 32.1 & 0.127 & 3.26 & & & & \\
\hline$\sigma$ & 11.0 & 0.62 & 0.50 & 0.6 & 0.122 & 0.99 & & & & \\
\hline
\end{tabular}

Note: $\mathrm{m}=$ mean; $\sigma=$ deviation. 


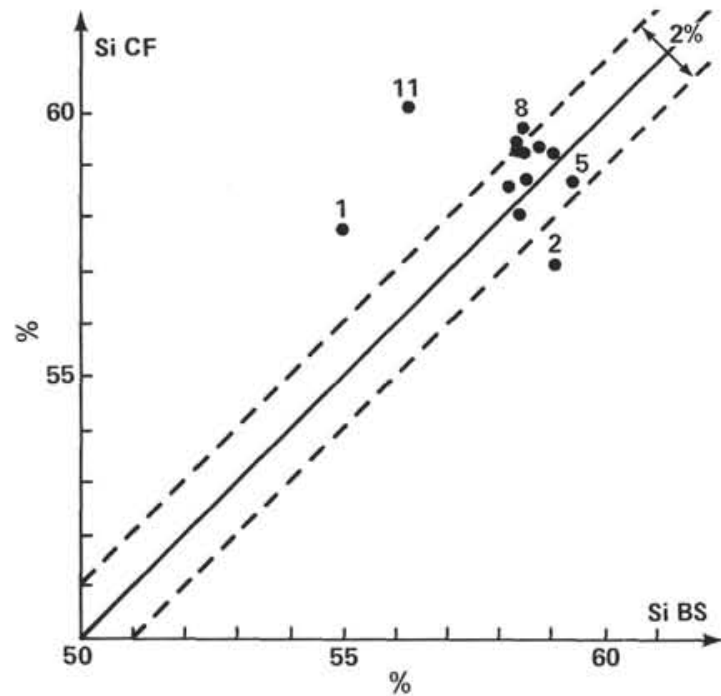

A

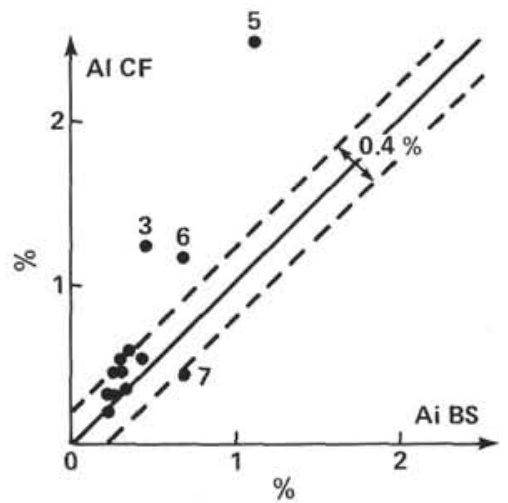

B

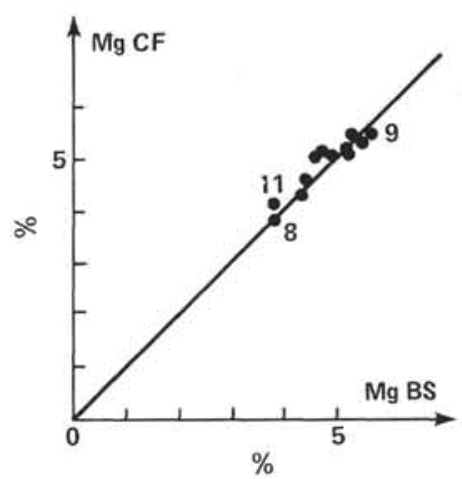

C

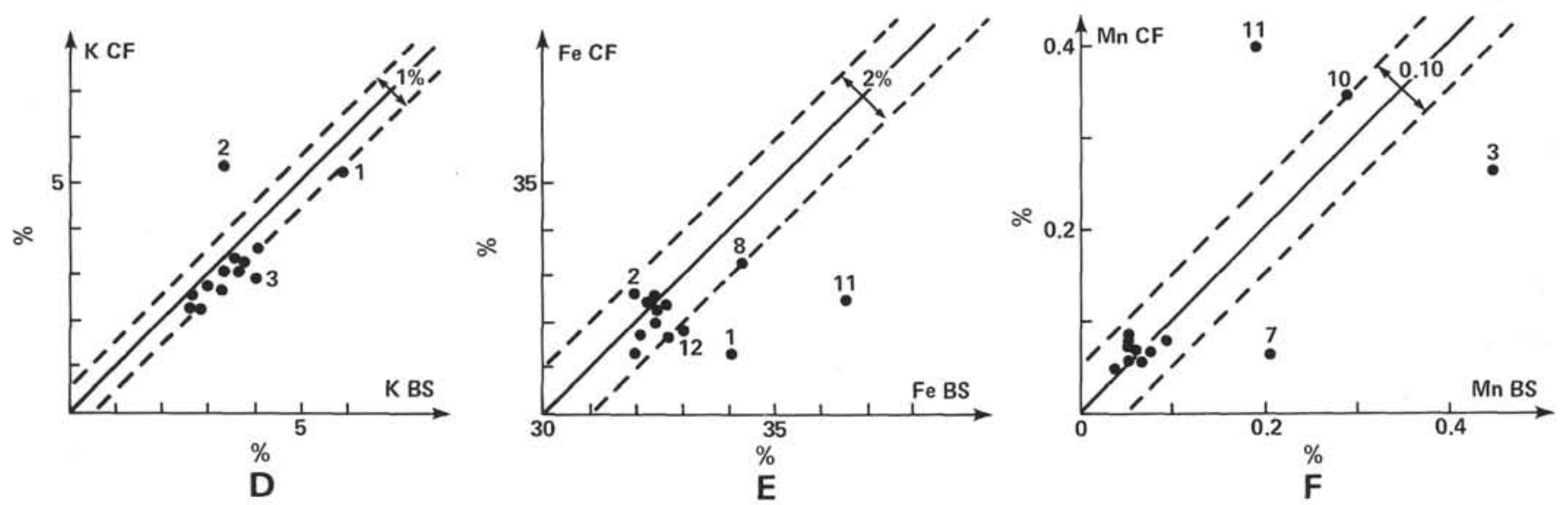

Figure 2. Correlation between (A) $\mathrm{SiO}_{2}$, (B) $\mathrm{Al}_{2} \mathrm{O}_{3}$, (C) $\mathrm{MgO}$, (D) $\mathrm{K}_{2} \mathrm{O}$, (E) $\mathrm{Fe}_{2} \mathrm{O}_{3}$, and ( $\mathrm{F}$ ) $\mathrm{Mn}_{3} \mathrm{O}_{4}$ contents of the bulk sediment and the clay fraction samples of hydrothermal clay, Leg 70, Holes 506, 506C, and 507D. Weight oxide content in percent recalculated on $\mathrm{SiO}_{2}+\mathrm{Al}_{2} \mathrm{O}_{3}+\mathrm{MgO}+$ $\mathrm{K}_{2} \mathrm{O}+\mathrm{Fe}_{2} \mathrm{O}_{3}+\mathrm{Mn}_{3} \mathrm{O}_{4}=100$. (See legend Fig. 1.)

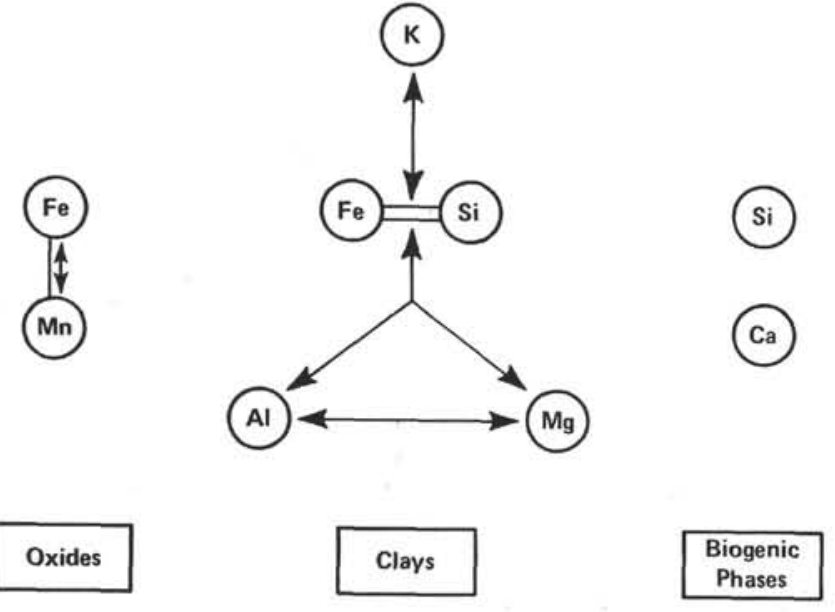

Figure 3. Schematic representation of repartition of the major elements among the mineralogical phases forming the hydrothermal deposits from the Galapagos mounds (Leg 70).
Table 9. Structural formulas of clays established with chemical analyses of clay fraction recalculated for $\mathrm{SiO}_{2}+\mathrm{Al}_{2} \mathrm{O}_{3}+\mathrm{MgO}+\mathrm{Fe}_{2} \mathrm{O}_{3}$ $+\mathrm{Mn}_{3} \mathrm{O}_{4}+\mathrm{K}_{2} \mathrm{O}=100$, on the basis of 22 charges.

\begin{tabular}{lcclccccc}
\hline $\begin{array}{c}\text { Sample } \\
\text { (interval in cm) }\end{array}$ & $\mathrm{Si}$ & $\begin{array}{c}\mathrm{Al} \\
\text { (tetr.) }\end{array}$ & $\begin{array}{c}\mathrm{Al} \\
\text { (oct.) }\end{array}$ & $\mathrm{Fe}$ & $\mathrm{Mg}$ & $\mathrm{Mn}$ & $\mathrm{K}$ & $\begin{array}{c}\text { Octahedral } \\
\text { Cations }\end{array}$ \\
\hline 506-6-2, 39-41 & 3.907 & 0.034 & 0 & 1.592 & 0.513 & 0.003 & 0.458 & 2.108 \\
506-6-2, 127-129 & 3.836 & 0.026 & 0 & 1.674 & 0.524 & 0.004 & 0.462 & 2.220 \\
506C-3-2, 0-150 & 3.948 & 0.052 & 0.043 & 1.588 & 0.451 & 0.003 & 0.245 & 2.086 \\
506C-3-1, 0-150 & 3.967 & 0.033 & 0.010 & 1.604 & 0.436 & 0.003 & 0.311 & 2.053 \\
506C-3-3, 93-113 & 3.957 & 0.042 & 0 & 1.587 & 0.501 & 0.003 & 0.265 & 2.094 \\
506C-4-1, 121-125 & 3.883 & 0.117 & 0.078 & 1.558 & 0.499 & 0.004 & 0.198 & 2.140 \\
506C-4-2, 122-126 & 3.910 & 0.090 & 0.002 & 1.614 & 0.502 & 0.004 & 0.229 & 2.122 \\
506C-4-3, 53-57 & 3.947 & 0.034 & 0 & 1.618 & 0.507 & 0.003 & 0.223 & 2.128 \\
507D-6-1, 12-22 & 3.977 & 0.023 & 0.002 & 1.687 & 0.380 & 0.003 & 0.189 & 2.072 \\
507D-6-2, 37-41 & 3.924 & 0.017 & 0 & 1.633 & 0.536 & 0.003 & 0.276 & 2.172 \\
507D-6-2, 103-107 & 3.898 & 0.043 & 0 & 1.641 & 0.532 & 0.002 & 0.288 & 2.175 \\
507D-6-2, 90-130 & 3.952 & 0.025 & 0 & 1.605 & 0.516 & 0.004 & 0.259 & 2.124 \\
507D-7-1, 16-21 & 3.997 & 0.003 & 0.031 & 1.627 & 0.405 & 0.003 & 0.211 & 2.066 \\
\hline
\end{tabular}

Note: Structural formulas calculated with the mean value of $\mathrm{Mn}_{3} \mathrm{O}_{4}=0.065 \%$. 


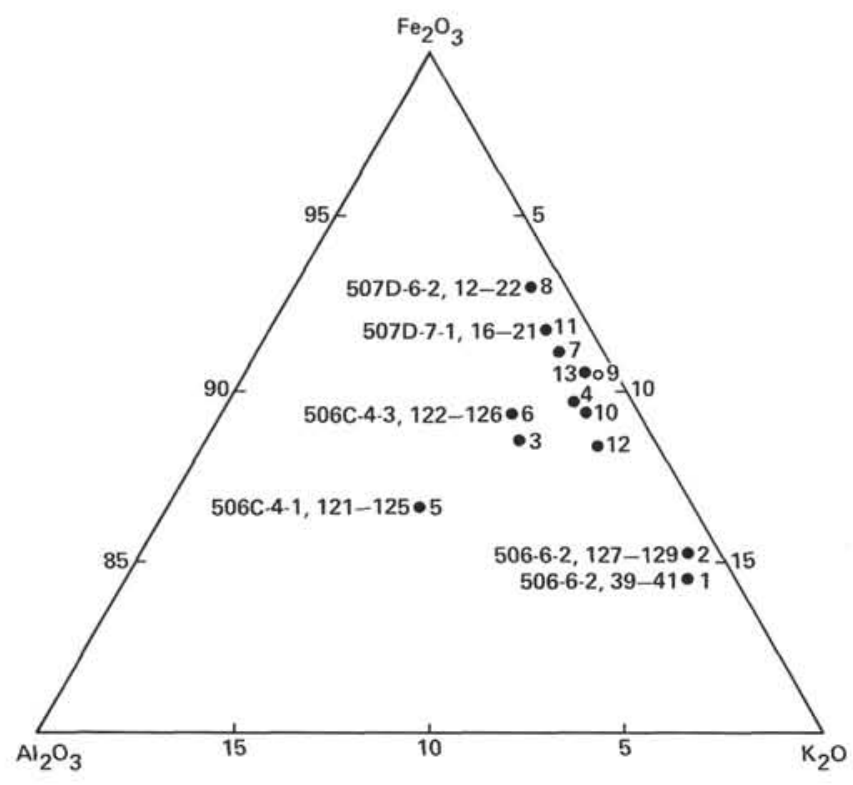

Figure 4. Ternary diagram $\left(\mathrm{Fe}_{2} \mathrm{O}_{3}, \mathrm{Al}_{2} \mathrm{O}_{3}, \mathrm{~K}_{2} \mathrm{O}\right)$ showing the composition of clay fraction samples from Leg 70 , Holes 506, 506C, and 507D.

\section{Trace Element Geochemistry}

Strontium contents are usually related to $\mathrm{CaCO}_{3}$ contents (Turekian, 1964). The variations in $\mathrm{Sr}$ contents in carbonate sediments are often used as indicators of the diagenetic evolution of these sediments (e.g., Karpoff, 1980). Even though the biogenic carbonates are not very important in the green clay layers of the Galapagos thermal mounds, these hydrothermal sediments have anomalously high $\mathrm{Sr}$ contents compared with those of the $\mathrm{Pa}$ cific pelagic sediments (see Figs. 5A and 5B). It appears that the more aluminous clays are also the richest in $\mathrm{Sr}$. One could explain these high $\mathrm{Sr}$ contents as the result of a selective "trapping" of $\mathrm{Sr}$ by the hydrothermal clays which precipitated at the same time that the biogenic carbonates were being dissolved by the hydrothermal solutions. Alternatively, part of the $\mathrm{Sr}$ could be derived from the hydrothermally altered basalts as suggested by Hoffert et al. (1978) in the case of the hydrothermal deposits of the FAMOUS area.

Barium content variations in pelagic sediments are often related to the abundance of siliceous organisms. They can also indicate diagenetic evolution of siliceous biogenic sediments. Barium content can be high in sediments receiving a volcanic contribution (Karpoff, 1980).

Barium is sometimes present in volcanogenic-rich sediment in silicates such as harmotome, or more often as barite, or associated with $\mathrm{Fe}-\mathrm{Mn}$ oxides. In the hydrothermal green clays from the Galapagos mounds, the highest $\mathrm{Ba}$ content was found in Sample 506C-4-1, 121$125 \mathrm{~cm}$, where an unidentified mineral, possibly barite or a zeolite, was observed (see Plate 2, Fig. 5). The other high $\mathrm{Ba}$ contents probably correspond to the presence of barite in samples where the smectites are the most aluminum rich. The presence of $\mathrm{Ba}$ results from the action of the hydrothermal solutions on the biogeneous siliceous component of the sediments-the latter being dissolved and substituted by clay minerals.
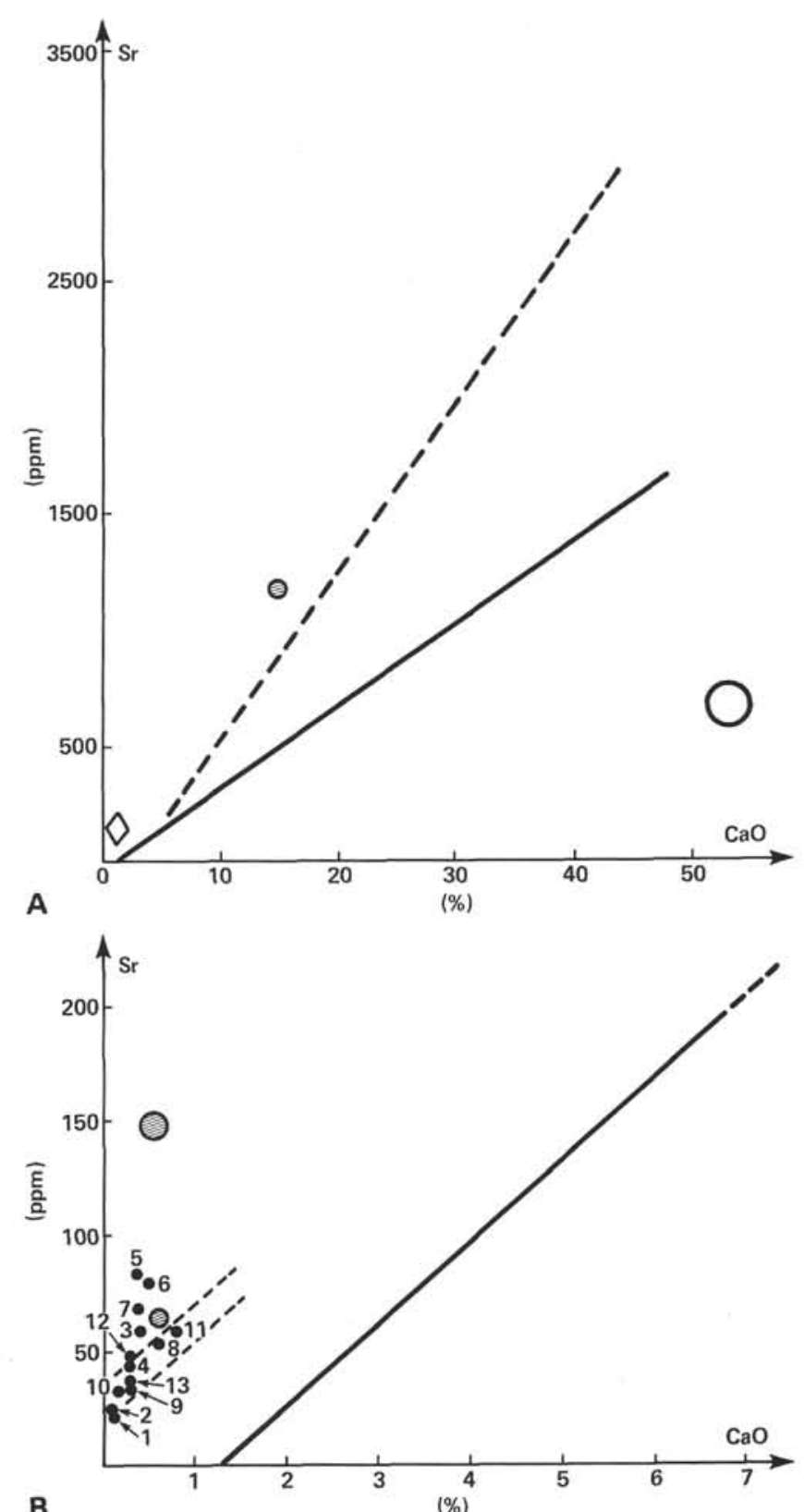

B

(\%)

Figure 5. A. Correlation between the $\mathrm{Sr}(\mathrm{ppm})$ and $\mathrm{CaO}(\%)$ contents of bulk hydrothermal clays and calcareous sediments. Regression lines based on data from Leg 54 (solid line is regression for biogenic calcareous ooze from Site 424; Hoffert et al., 1980) and Leg 55 (dashed line is regression for marly calcareous ooze and nannofossil ooze; hashed circle is volcanic rich mud; open circle is reefal sand; Karpoff, 1980). B. Correlation between $\mathrm{Sr}(\mathrm{ppm})$ and $\mathrm{CaO}$ (\%) contents of bulk hydrothermal clays (diamond) from Leg 70 , Holes 506, 506C, and 507D. Comparison with the data from hydrothermal clays from Site 524, Leg 54 (hashed circles; Hoffert et al., 1980). Dashed lines are equivalent regression lines for biogenic calcareous oozes. Solid line is regression based on calcareous oozes from Leg 54, Site $424(\mathrm{CaO}$ wt. $\%=0.0275 \mathrm{Sr}+1.31)$. (See caption to Fig. 1.)

\section{Other Trace Elements: $\mathrm{V}, \mathrm{Ni}, \mathrm{Zn}$, and $\mathrm{Cu}$}

The hydrothermal clay from the Galapagos mounds is generally poor in transition metals such as $\mathrm{V}, \mathrm{Ni}, \mathrm{Zn}$, and $\mathrm{Cu}$ as already noted in the data of Leg 54 , Site 424 , and the FAMOUS area (Hekinian et al., 1978; Hoffert 
et al., 1980). However, $\mathrm{V}, \mathrm{Ni}, \mathrm{Zn}$, and $\mathrm{Cu}$ are more abundant in samples from Hole $506 \mathrm{C}$, which also contain the unidentified mineral (barite or zeolite), the more aluminous clays, and more particularly, the $\mathrm{Fe}-\mathrm{Mn}$ oxides. This enrichment in transition elements and aluminum, as well as the presence of authigenic minerals besides the clays, could indicate a more advanced "diagenesis" of some hydrothermal clays from the Galapagos mounds.

\section{CONCLUSIONS}

The 13 studied samples of green clays from Holes 506, 506C, and 507D from the hydrothermal mounds south of the Galapagos Spreading Center appear to be made up of essentially mixed-layer nontronite-mica (celadonite) with a predominance of smectite. Only one sample $(506-6-2,39-41 \mathrm{~cm})$ is formed mainly by celadonite, the smectitic contribution to the mixed-layer mineral being much smaller than in the other $12 \mathrm{sam}$ ples. The clay fractions are iron-rich and $\mathrm{Al}, \mathrm{Mg}$-poor, but the most celadonite-rich sample is one of the two that are much richer in $\mathrm{K}$ than the others. Another sample $(506 \mathrm{C}-4-1,121-125 \mathrm{~cm})$ is more $\mathrm{Al}$ - and $\mathrm{Sr}$-rich than the others.

The bulk sediment samples also contain traces of $\mathrm{Fe}-$ Mn oxides, mainly as microconcretions. The bulk sediment sample corresponding to the Al-rich clay fraction is also more $\mathrm{Ba}$-rich and contains an unidentified authigenic mineral, possibly barite or a zeolite.

Trace-element geochemistry appears to confirm the differentiation of the green hydrothermal clays between $\mathrm{K}$-rich and $\mathrm{Al}$-rich end members. In the latter case, an enrichment in transition metals, such as $\mathrm{V}, \mathrm{Ni}, \mathrm{Zn}$, and $\mathrm{Cu}$, as well as in $\mathrm{Ba}$ is also noticed, which could probably be the result of diagenesis.

\section{ACKNOWLEDGMENTS}

Most of the analytical work for the present study was carried out during J. H.'s leave of absence from the University of Miami and his stay as visiting professor at the Institut de Géologie of the Université de Strasbourg. He wishes to thank all the faculty and staff members of the Centre de Sédimentologie et Géochimie de la Surface of Strasbourg and, more particularly, Professors Millot and J. Lucas, Director and Vice Director of the Centre. Professor G. Dunoyer de Segonzac is thanked for his brotherly support to J. H. during his year at Strasbourg.

We wish to thank MM. P. Karcher, Larqué, the Wendlings, and Dr. F. Weber for their help in the X-ray diffraction and sample preparation laboratories, and Dr. Y. Besnus for carrying out the chemical analysis.

J. H. benefited from numerous discussions with J. Alt. Finally, B. Glaccum, E. Hall, T. Hood, J. Johnson, C. Romon, and N. Sempter drafted, typed, calculated, and helped in many other ways during manuscript preparation. We are grateful to all of them for their collaboration.

This research was supported by the C.N.R.S. (France). Contribution of the University of Miami.

\section{REFERENCES}

Bentor, Y. K., and Kastner, M., 1965. Note on the mineralogy and origin of glauconite. J. Sediment. Petrol., 35(1):155-166.
Besnus, Y., and Lucas, J., 1968. Méthodes de dosage de 18 éléments majeurs et traces dans les roches sédimentaires et les produits d'alteration par spactrometrie à lecture directe. Coll. Nat. C.N.R.S., 923:93-106.

Besnus, Y., and Rouault, R., 1973. Une méthode d'analyse des roches au spectromètre d'arc à lecture directe par un depositif d'électrode ratative. Analusis, 2:111-116.

Birch, G. F., Willis, J. P., and Rickard, R. S., 1976. An electron micro study of glauconite from the continental margins of the West Coast of South Africa. Mar. Geol., 22:271-283.

Bischoff, J. L., 1972. A ferroan nontronite from the Red Sea geothermal system. Clays Clay Miner., 20:217-223.

Cann, J. R., Winter, C. K., and Pritchard, R. G., 1977. A hydrothermal deposit from the floor of the Gulf of Aden. Miner. Mag., 41: 193-199.

Corliss, J. B., Lyle, M., Dymond, J., and Crane, K., 1978. The chemistry of hydrothermal mounds near the Galapagos Rift. Earth Planet. Sci. Lett., 40:12-14.

Grill, E. V., Chase, R. L., MacDonald, R. D., and Murray, J. W., 1981. A hydrothermal deposit from the Explorer Ridge in the northeast Pacific Ocean. Earth Planet. Sci. Lett., 52:142-150.

Hekinian, R., Rosendahl, B. R., Cronan, D. S., Dmitriev, Y., Fodor, R. V., Groll, R. M., Hoffert, M., Humphris, S. E., Mattey, D. P., and Natland, J., 1976. Hydrothermal deposits and associated basement rocks from the Galapagos Spreading Center. Oceanol. Acta, 1:473-482.

Hoffert, M., Perseil, A., Hekinian, R., Needham, H. P., Francheteau, J., and Le Pichon, X., 1978. Hydrothermal deposits sampled by diving saucer in transform Fault " $\mathrm{A}$ " near $37^{\circ} \mathrm{N}$ on the Mid-Atlantic Ridge, FAMOUS area. Oceanol. Acta, 1:73-86.

Hoffert, M., Person, A., Courtois, C., Karpoff, A. M., and Trauth, D., 1980. Sedimentology, mineralogy, and geochemistry of hydrothermal deposits from Holes 424, 424A, 424B and 424C. (Galapagos Spreading Center). In Rosendahl, B. R., Hekinian, R., et al., Init. Repts. DSDP, 54: Washington D.C. (U.S. Govt. Printing Office), 339-376.

Honnorez, J., Von Herzen, R. P., and Shipboard Scientific Party, 1981. Hydrothermal mounds and young ocean crust of the Galapagos: Preliminary Deep Sea Drilling results, Leg 70. Geol. Soc. Am. Bull., 92:457-472.

Karpoff, A. M., 1980. The sedimentary deposits of Suiko Seamount (Leg 55, Site 433): From the reef environment to the pelagic sedimentation. In Jackson, E. D., Koizumi, I., et al., Init. Repts. DSDP, 55: Washington (U.S. Govt. Printing Office), 491-501.

Karpoff, A. M., Hoffert, M., and Clauer, N., 1981. Mineralogical and Geochemical modifications along a sedimentary sequence: From siliceous ooze to "red clay." In Thiede, J., Vallier, T. L., et al., Init. Repts. DSDP, 62: Washington (U.S. Govt Printing Office), 759-772.

Lalou, C., Brichet, E., Ku, T. H., and Jehanro, C., 1977. Radiochemical, scanning electron microscope and X-ray dispersive energy (EDAX) studies of FAMOUS hydrothermal deposit. Mar. Geol., 24:245-258.

Lonsdale, P., 1977. Deep-tow observations at the mounds abyssal hydrothermal field, Galapagos Rift. Earth Planet. Sci. Lett., 36: 92-110.

Shutov, V. D., Katz, M. Y., Drits, V. A., Sokolova, A. L., and Kazakov, G. A., 1972. Crystallochemical heterogeneity of glauconite as depending on the conditions of its formation and postsedimentary change. Proc. Int. Clay Conf. Madrid, pp. 327-339.

Trauth, D., Ehret, G., Eberhart, J. P., and Weber, F., 1977. Microscopie électronique et minéraux argileux: Résultats obtenus et orientations actuelles. Notes Techniques Inst. Geol. Université Strasbourg., 7.

Turekian, K. K., 1964. The marine geochemistry of strontium. Geochim. Cosmochim. Acta, 28:1479-1496.

Williams, D. L., Green, K., van Andel, Tj. H., Von Herzen, R. P. Dymond, J. R., and Crane, K., 1979. The hydrothermal mounds of the Galapagos Rift: Observations with DSRV Alvin and detailed heat flow studies. J. Geophys. Res., 84(B13):7467-7484. 

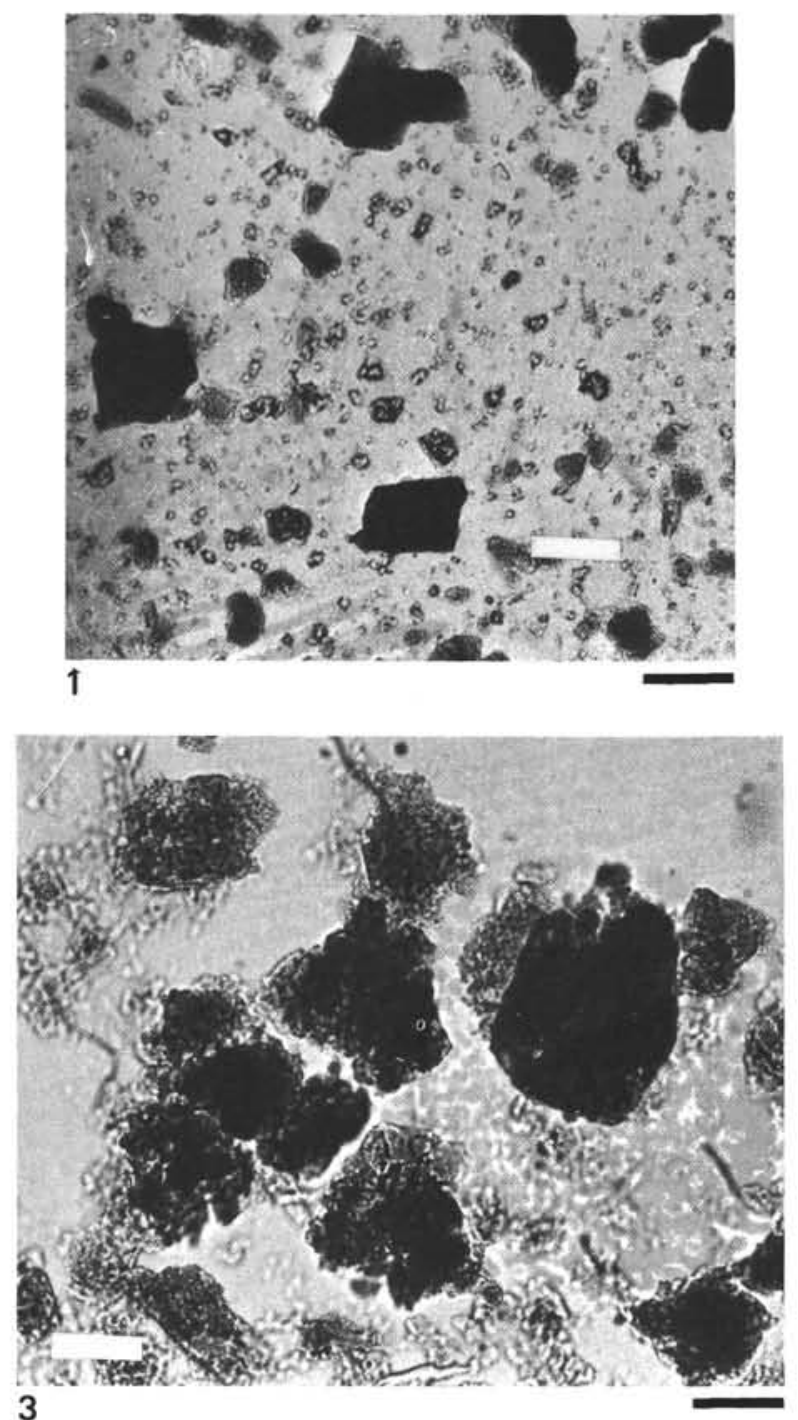

3

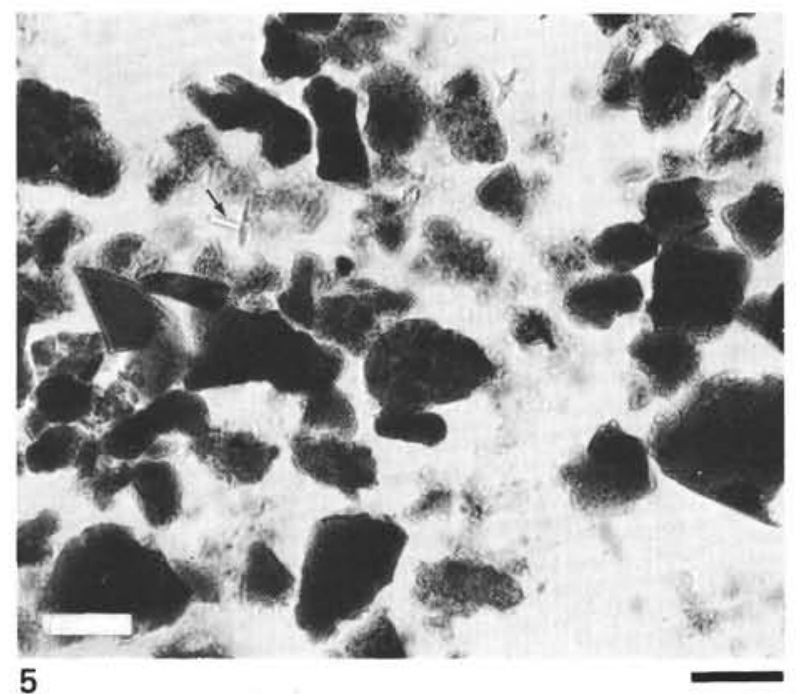

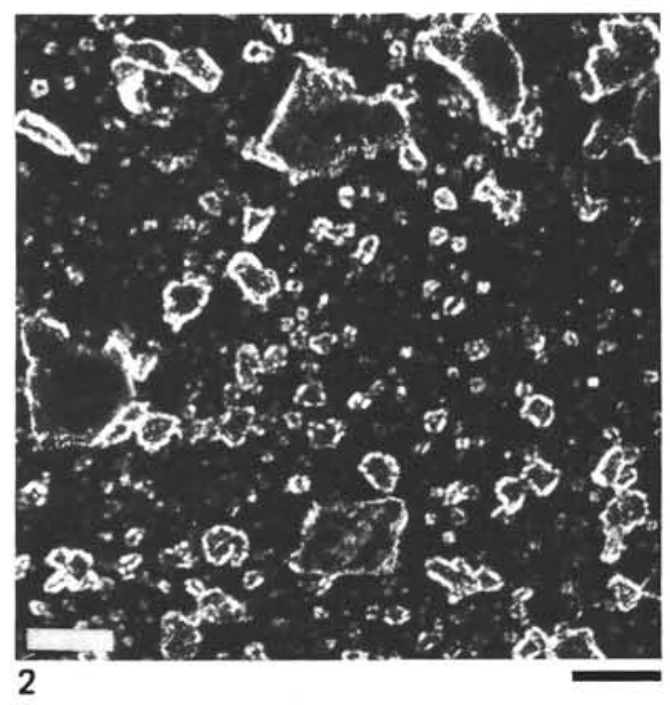
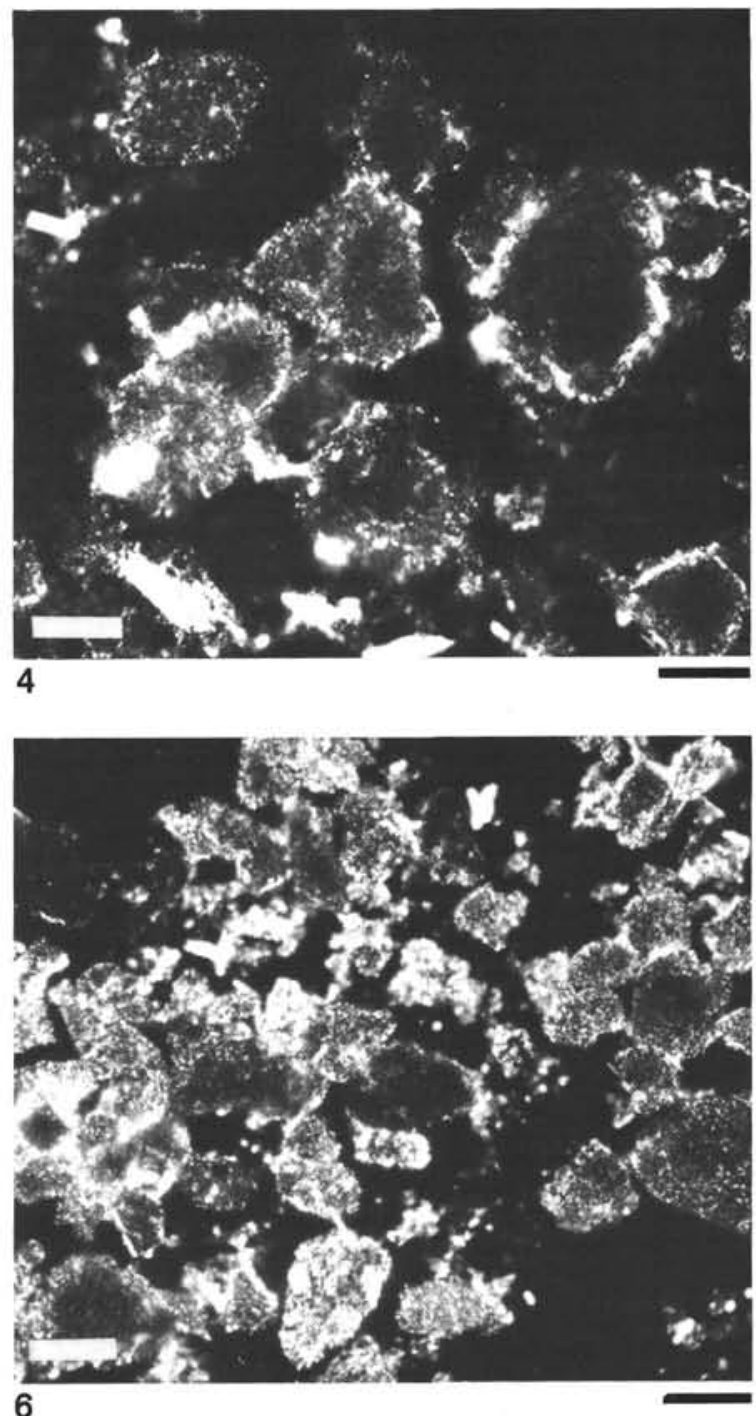

Plate 1. Major types of clay particles. Photomicrographs of smear slides in plane polarized light. 1 . Sample 506-6-2, 39-41 cm; morphology of Type 1 particles characterized by straight edges (scale bar $=250 \mu \mathrm{m})$. 2. Same as Figure 1 between crossed polars; notice birefringent rim at particle outlines. 3. Sample 506-6-2, 127-129 cm; morphology of Type 2 particles characterized by irregular, granular outlines (scale bar $=100$ $\mu \mathrm{m})$. 4. Same as Figure 3 between crossed polars. 5. Sample 506C-3-1, 0-150 cm; morphology of Type 3 particles; slabs with straight edges $(\rightarrow=$ calcite crystals; scarce small Type 2 granular particles); (scale bar $=250 \mu \mathrm{m}$ ). 6 . Same as Figure 5 between crossed polars. 

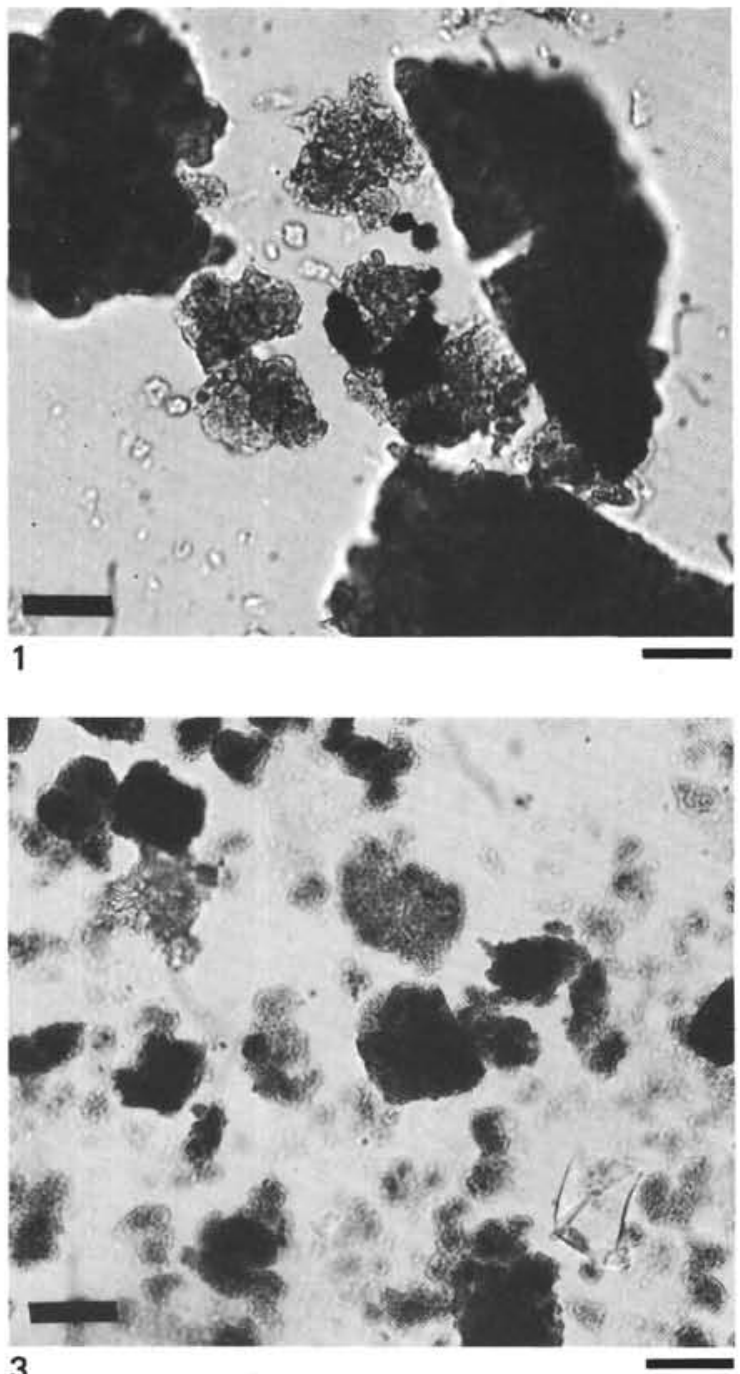

3

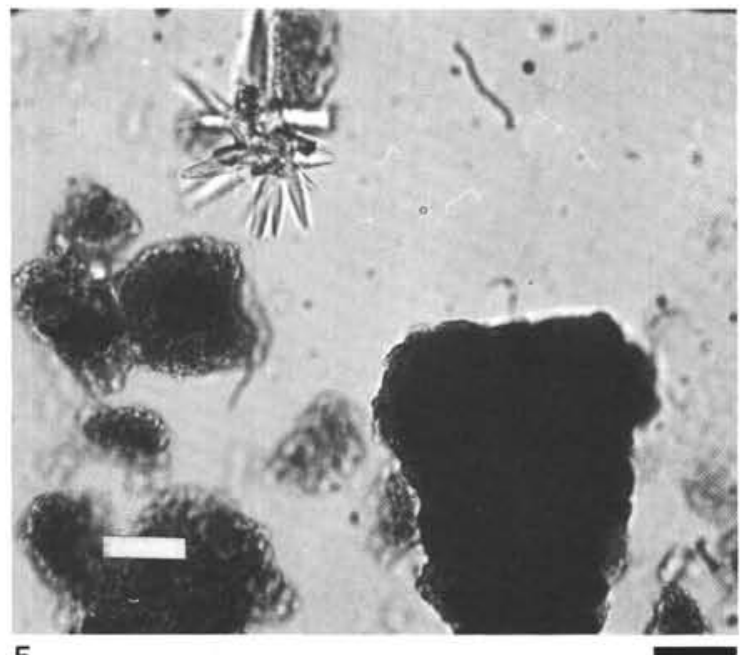

5
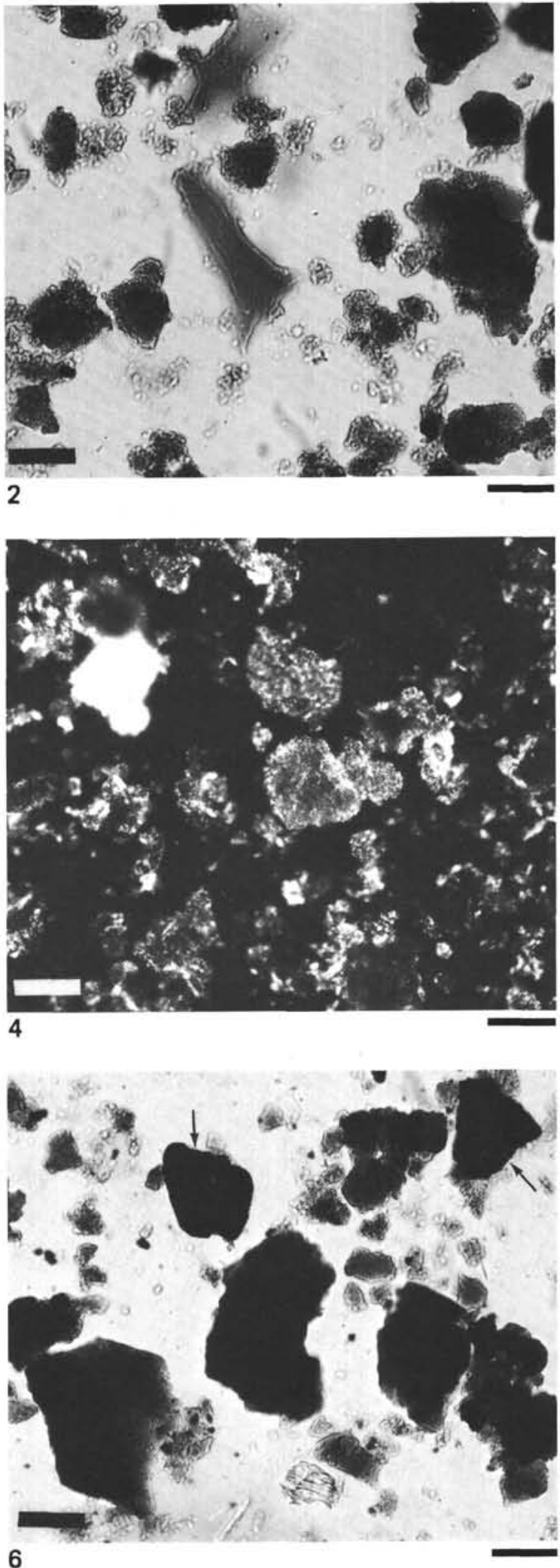

Plate 2. Major types of clay particles. Photomicrographs of smear slides in plane polarized light. 1. Sample 507D-6-1, 12-22 cm; small granular aggregates with microconcretions of Fe-Mn oxides; bigger right-edged Type 1 particles (scale bar $=100 \mu \mathrm{m}$ ). 2. Same sample as Figure 1; small granular Type 2 particles, bigger watered ("Moires") particles, and diffuse-edged particles (scale bar $=250 \mu \mathrm{m}$ ). 3 . Sample 506-4-1, 121-125 $\mathrm{cm}$; Type 2 granular particles, fish debris, and barite or zeolite(?) crystal aggregate (scale bar $=250 \mu \mathrm{m}$ ). 4 . Same as Figure 3 between crossed polars. 5. Detail of preceding photographs showing the barite or zeolite needle aggregates (scale bar $=100 \mu \mathrm{m}$ ). 6 . Sample 506C-3-1, 0-150 $\mathrm{cm}$; Type 3 particles with Fe-Mn micronodules (scale bar $=250 \mu \mathrm{m}$ ). 


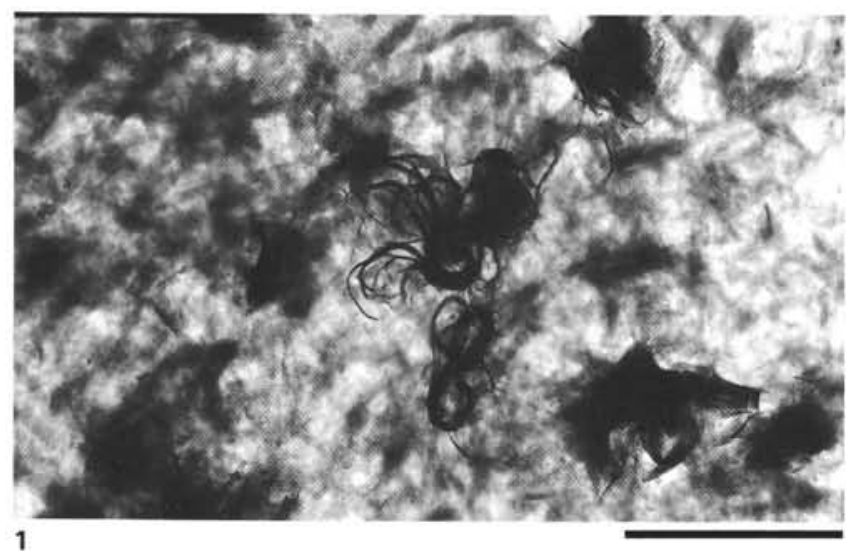

1

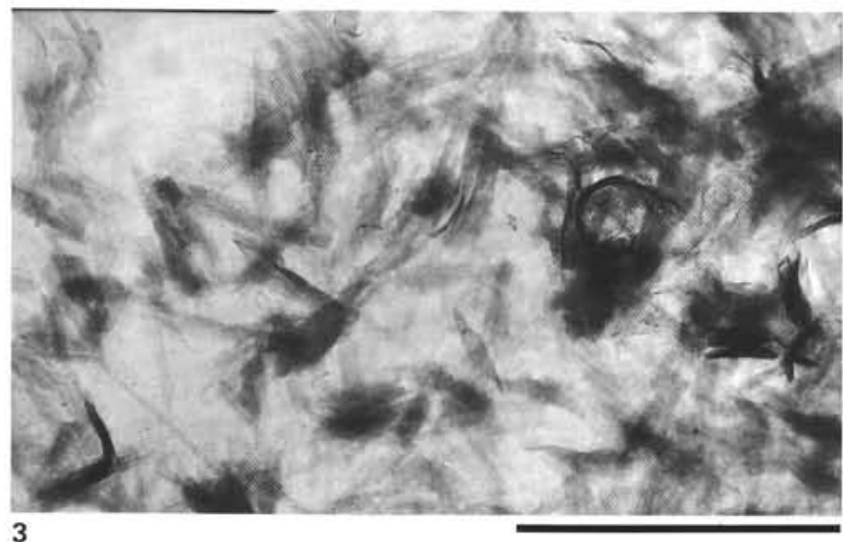

3

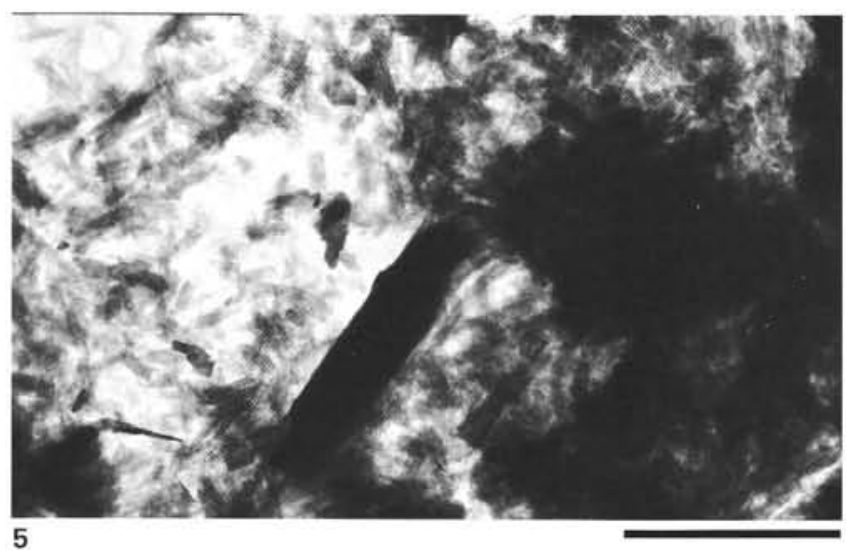

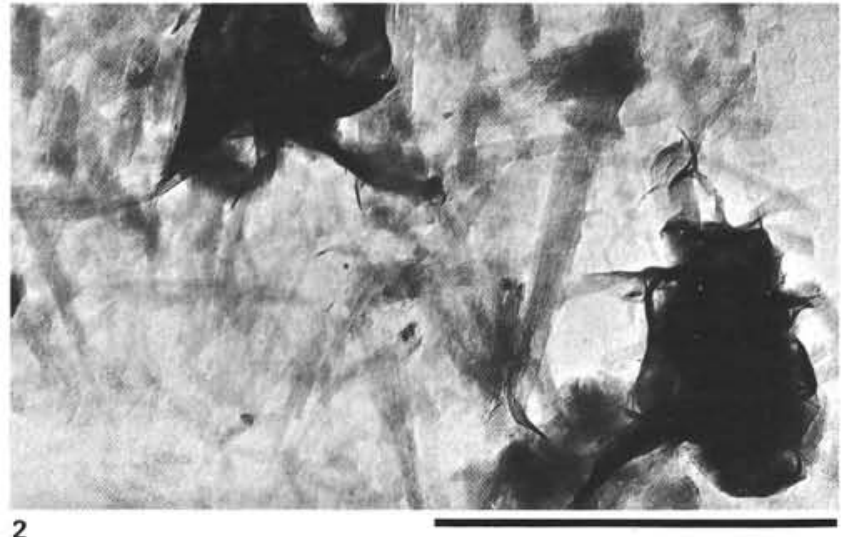

2

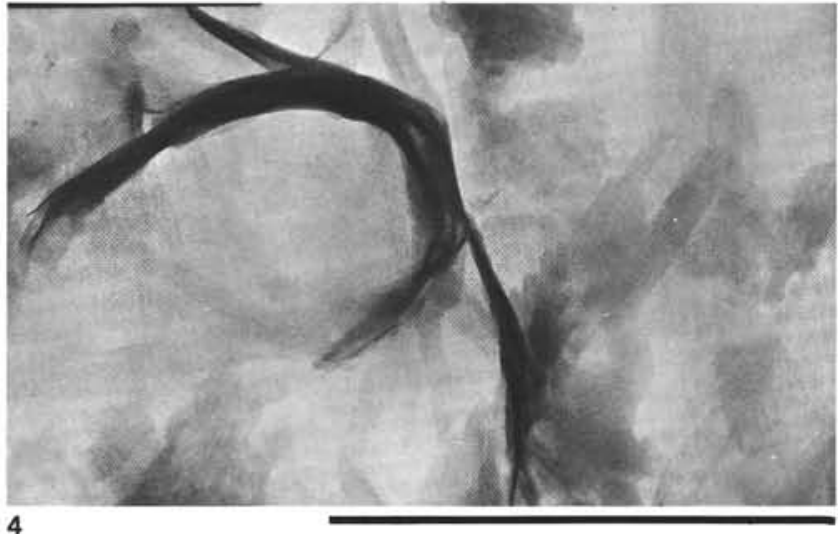

4

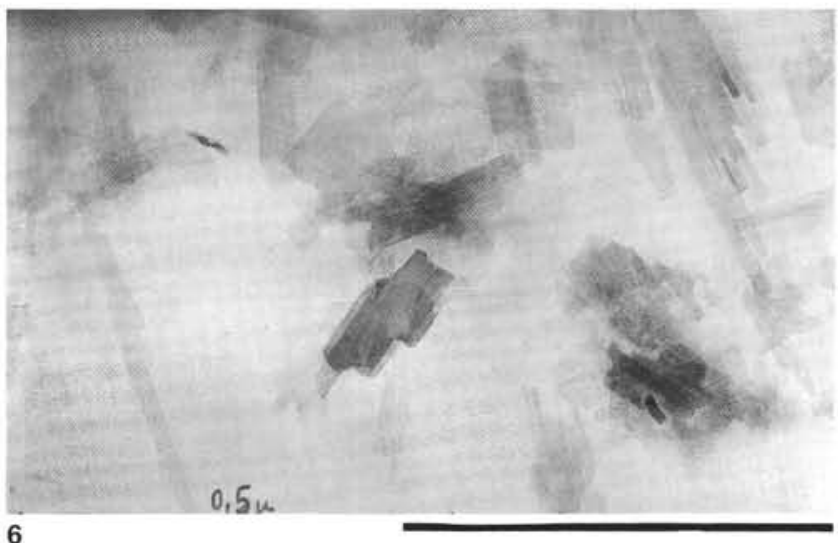

Plate 3. Transmission electron microscope photomicrographs of clay fractions. 1 . The $<2 \mu \mathrm{m}$ fraction from Sample 506C-3-1, 0-150 cm, illustrating a typical example of clay mineral morphologies of the Galapagos mounds hydrothermal green clays: mostly lath-shaped clay particles with a few curled clay flakes (scale bar $=1 \mu \mathrm{m}$ ). 2. The 0.4 to $2 \mu \mathrm{m}$ fraction from the same sample as Figure 1 . Both lath- and curl-shaped clay particles are present (scale bar $=1 \mu \mathrm{m}$ ). 3. The $<0.4 \mu \mathrm{m}$ fraction from the same sample as Figures 1 and 2 ; the clay mineral morphologies are essentially the same as in the coarser fraction (scale bar $=0.5 \mu \mathrm{m}$ ). 4 . The $<0.4 \mu \mathrm{m}$ fraction from Sample 507D-6-2, 90-130 cm. Both lath-and curl-shaped clay particles are also present as in the sample illustrated in Figures 2 and 3; one large curled flake shaped clay particle (scale bar $=$ $0.5 \mu \mathrm{m})$. 5. The $<2 \mu$ m clay fraction from Sample 506-6-2, 39-41 cm, illustrating the morphology of the clay mineral present in this exceptional sample; only lath-shaped clay particles are present (scale bar $=1 \mu \mathrm{m}$ ). 6 . Same as Figure 5, but scale bar $=0.5 \mu \mathrm{m}$. 